\title{
Cultura Cultura
}

Revista de Historia Teorid das ldeaias - Revista de História e Teoria das Ideias

Vol. 23 | 2006

Ideia(s) de Tempo(s)

\section{O cômputo do tempo na civilização indiana}

Time reckoning in indian civilization

\section{Luís Filipe F. R. Thomaz}

\section{OpenEdition}

\section{Journals}

Edição electrónica

URL: http://journals.openedition.org/cultura/1429

DOI: 10.4000/cultura.1429

ISSN: 2183-2021

\section{Editora}

Centro de História da Cultura

\section{Edição impressa}

Data de publição: 1 Janeiro 2006

Paginação: 179-207

ISSN: 0870-4546

\section{Refêrencia eletrónica}

Luís Filipe F. R. Thomaz, "O cômputo do tempo na civilização indiana », Cultura [Online], Vol. 23 | 2006, posto online no dia 25 março 2014, consultado a 19 abril 2019. URL : http://journals.openedition.org/ cultura/1429 ; DOI : 10.4000/cultura.1429

Este documento foi criado de forma automática no dia 19 Abril 2019.

(c) CHAM - Centro de Humanidades / Centre for the Humanities 


\section{O cômputo do tempo na civilização indiana}

Time reckoning in indian civilization

Luís Filipe F. R. Thomaz

1 O cômputo do tempo é, na Índia como no resto do mundo, baseado sobre as revoluções astrais. O grande problema que se lhe põe é, pois, como em toda a parte, o de compatibilizar num sistema coerente unidades naturais de tempo, como o dia, a lunação e o ano, que não são rigorosamente divisíveis uns pelos outros. A solução não pode ser senão a de adoptar um sistema em maior ou menor medida convencional, a que chamamos calendário, em que aos vários períodos se fixa arbitrariamente um começo não necessariamente coincidente com um acontecimento astronómico preciso, ajustando-se, contudo, o calendário convencional à realidade física mediante a inserção periódica de unidades de tempo suplementares: é assim que se obtém, por exemplo, uma unidade de tempo próxima da lunação real (c. 29 dias 1/2), adoptando para os meses civis uma duração alternada de 29 e 30 dias, uma unidade tempo próxima do ano astronómico inserindo de quatro em quatro anos um dia a mais no ano solar, que assim permanece grosso modo equivalente a 365 dias 1/4, etc. Quando tais ajustamentos não têm lugar obtêm-se unidades de tempo apenas vagamente correspondentes a revoluções celestes, como é o caso da semana, que se tornou meramente convencional, embora a sua duração corresponda aproximadamente à de uma fase da Lua. Para além destas unidades de tempo outras existem em todas as civilizações de origem puramente convencional, fruto da especulação matemática e não da observação dos céus; tal é nomeadamente o caso da subdivisão do dia em doze (ou vinte e quatro) horas, a da hora em 60 minutos e a destes em 60 segundos.

2 Com tudo isto topamos na Índia. O que, em contrapartida, parece característico da civilização indiana, pelo menos da da Índia clássica, é, por um lado, a extraordinária complexidade dos sistemas calendáricos e, por outro, a grande preocupação com a exactidão astronómica das datações - que, juntas, causam ao epigrafista que se aventura a decifrar inscrições indianas sérias dores de cabeça para reduzir ao nosso calendário as suas datas. 
3 A complexidade dos sistemas de cômputo do tempo - em que se conhecem mais de 30 eras diferentes para a contagem dos anos, o calendário solar ombreia com o lunar, o começo do mês coincide em certas regiões com a lua-cheia noutras com a lua-nova, e assim por diante - resulta da própria natureza histórica da civilização indiana, que apresenta, por assim dizer, um carácter fortemente "anarquista". A Índia apenas episodicamente conheceu uma unificação política; daí que jamais tenha havido, como houve no Império Romano ou na China, uma possibilidade de uniformizar por decreto o sistema calendárico. Para mais a doutrina política hindu confere ao estado um papel deveras apagado, não lhe reconhecendo o poder de modelar a sociedade, mas apenas o de zelar pelo bom funcionamento da ordem social vigente, tida como imutável. Daí a tendência para identificar a arte de governar com o que em sânscrito se designa por daṇ̂nâtiti ${ }^{1}$, composto que interpretado à letra significa "arte (nîti) de [manejar] o bastão (daṇ̂a)", ou seja, a arte de punir quem prevarica. A cultura dominante é uma cultura clerical, elaborada muito mais pelos brâmanes que pelos agentes da administração pública, e menos imposta à sociedade por coacção estatal que por uma espécie de sanção moral, que não implica senão um relativo consenso. ${ }^{2}$ Seja como for, a aparente desordem que caracteriza a astronomia hindu contrasta fortemente com o cariz oficial da astronomia chinesa ${ }^{3}$, já consignado pelo Shu Ching na lenda do mandato conferido pelo mítico imperador Yao (suposto ter reinado de 2357 a 2258 A. C.), um dos "heróis civilizadores" do Império do Meio, aos dois astrónomos Hsi e Ho para observarem os astros e estabelecerem um calendário em harmonia com os seus movimentos. ${ }^{4}$

4 Quanto à preocupação com a exactidão astronómica das datações, cujos efeitos práticos analisaremos mais abaixo, parece resultar da importância que a astrologia conserva na tradição hindu, aliada à ideia bramânica da eficácia dos ritos ex opere operato. 0 papel relevante que a astrologia desempenha na vida indiana foi já notado pelo escritor muçulmano Al-Bîrûnî, ${ }^{5}$ que viveu na corte de Ma h̆mûd de Ghazna, o primeiro conquistador maometano do Hindustão, e na sua célebre Descrição da Índia (Kitab al-ta'rîkh al-Hind), terminada em 1030 A. D., anotou: "a ciência da astronomia é entre eles a mais famosa, pois os negócios de sua religião estão-lhe de múltiplos modos ligados; se um homem quer ganhar o título de astrónomo cumpre-lhe não somente conhecer a astronomia científica e a matemática, mas também a astrologia". 6

5 Os antigos tratados rituais - os brâhmaṇas, considerados um apêndice ao Veda - insistem na necessidade de observar escrupulosamente toda uma infinidade de detalhes do cerimonial, incluindo a determinação do momento astrologicamente mais propício para a celebração de cada rito. E o sistema filosófico mais tradicional e mais bramânico, a Mîmâmsâ, que se apresenta como uma mera escola de exegese dos Vedas, sempre professou a doutrina da eficácia mágica dos rituais, supostos produzirem infalivelmente o efeito desejado desde que celebrados sem infracção da menor regra. ${ }^{7}$ Desse ponto de vista, o rigor objectivo da celebração do rito é mais importante que a intenção subjectiva dos celebrantes ou que as suas disposições interiores. A ânsia de rigor astronómico que ressumbra de muitas práticas de datação com que bastas vezes topamos prende-se, sem dúvida, ao formalismo dessas concepções.

\section{A época vêdica}

6 Na época vêdica (II milénio A. C., grosso modo) as observações astronómicas não tinham ainda, aparentemente, o rigor que viriam a adquirir mais tarde; mas as alusões dos textos 
ao calendário são demasiado lacónicas para que se possa conhecer em detalhe o sistema usado. ${ }^{8}$ Provavelmente coexistiriam diversas tradições - que a escolástica bramânica corporiza na distribuição dos textos sagrados e seus comentários por diversas "escolas vêdicas"9 - e daí o aparente desacordo entre uns textos e outros. Ao que parece usava-se geralmente um ano solar de doze meses de trinta dias cada um, o que perfaz um total de 360 dias, menos 5 e $1 / 4$ que o ano trópico; ${ }^{10}$ a esse ano alude metaforicamente um hino do Rgveda nos seguintes termos: "doze são as jantes, mas uma só a roda, três os cubos; mas quem o saberá? dentro dela 360 raios, fixos como pregos, ao mesmo tempo móveis e imóveis...". ${ }^{11}$ As jantes são os meses, a roda o ano, os cubos as três estações climáticas tradicionalmente consideradas na Índia (fria, quente e húmida) e os raios, obviamente, os dias do ano.

7 A correspondência deste ano de 360 dias com o ano trópico era provavelmente obtida pela inserção de um mês suplementar (certamente de 25 ou 26 dias) de cinco em cinco anos. A essa prática parecem aludir tanto o Rgveda como o Atharvaveda: o primeiro atribui a Varuna (a divindade do céu nocturno, correspondente ao Urano dos gregos) o conhecimento "dos doze meses, com suas produções, e de mais o que se lhes ajunta"; $;{ }^{12} \mathrm{o}$ segundo refere-se ao Criador "que compõe de noites e dias o edifício de trinta membros e o décimo-terceiro mês". ${ }^{13}$

8 De qualquer maneira o ciclo quinquenal não é absolutamente rigoroso, pois o total de 1830 dias que contém não é divisível por 365,2422 dias solares médios, duração do ano trópico; a diferença é de cerca de um centésimo de ano, ou seja, aproximadamente três dias e meio. Alguns autores admitem que se usasse também um ano lunar de 12 meses, alternadamenete de 29 e 30 dias, o que perfaz um total de 354 dias, a que se seguiriam 11 dias epagómenos para o ajustar com o ano solar, ${ }^{14}$ mas em tal sistema perder-se-ia ao cabo de um ano a coincidência entre o começo dos meses e a lua-nova.

O ano é normalmente designado por varṣa, "chuva", o que mostra que na sua origem está mais a observação do clima do que a dos astros. Conhecem-se os nomes dos doze meses do calendário vêdico, que comportava ainda uma divisão do ano em seis "estações" de dois meses cada uma; assim a estação chamada vasanta (primavera), que começa no equinócio de Março, compreende os meses madhu ("mel, néctar") e mâdhava ("doçura primaveril"); grișma ("calor estival") compreende os meses çukra ("replandecente") e çuci ("branco, luminoso"); varșa ("chuva"), correspondente à monção chuvosa, os meses nabhas ("nuvem") e nabhasya ("nublado, enevoado"); çarad ("outono"), que começa no equinócio de Setembro, os meses iṣa ("sucolento") e ûrja ("vigoroso"); hemanta ("inverno") os meses sahas ("potência, poderio") e sahasya ("poderoso"); e finalmente çiçira ("frescura, cacimba") os meses tapas ("calor") e tapasya (lit. "quentura, fervor" e daí "devoção austera"). Como se vê, pelo menos os nomes atribuídos aos dois últimos meses estão longe de corresponder às respectivas condições climáticas, facto que tem conduzido a engenhosas hipóteses interpretativas que não cabe discutir aqui.

10 O Atharvaveda e, após ele, diversos textos em prosa apensos aos quatro vedas clássicos, referem-se a uma curiosa unidade astronómica, que viria a ter na astronomia indiana um grande futuro: o nakșatra, termo que em sentido próprio significa "estrela" ou ainda "constelação", mas em sentido técnico designa cada uma das "mansões lunares", ou seja, das constelações que, no seu movimento em torno da Terra, a Lua percorre durante uma revolução completa. A revolução sideral ${ }^{15}$ da Lua dura na realidade 27 dias, 7 horas, 43 minutos 11 segundos e $1 / 2$, de modo que existem ao todo 27 ou 28 mansões lunares, conforme se considere ou não a fracção de sete horas e tal necessária para completar o 
movimento; ao que parece os textos mais antigos referiam apenas 27 mansões lunares, mas os mais modernos já 28 , sendo uma delas (a $20^{\mathrm{a}}$, dita abhijit ou abhijita, lit. "que ganha, vitoriosa") mais curta. Assim no Atharvaveda, XIX, viii, 1-2: "Quantas constelações haja no céu, nos ares, nas águas ou na Terra, quantas nas montanhas ou nos quadrantes dos céus, e a Lua as percorre em tempos fixos, que todas elas me sejam propícias! Que as vinte e oito, benignas, com a Lua, me concedam felicidade e paz!".

11 É possível que o conceito indiano de nakșatra ou "mansão lunar" esteja na origem do conceito de hsiu na astronomia chinesa, também em número de 28 , embora estes sejam medidos sobre o equador celeste e não sobre a eclíptica, ${ }^{16}$ delimitando assim sectores meridianos do céu, definidos pela ascensão recta e não pela longitude. ${ }^{17} \mathrm{O}$ mesmo conceito está provavelmente também na origem dos manâzil (plural de manzil, "morada, mansão") ou manâzil alqamr ("moradas da Lua") da astronomia árabe medieval. ${ }^{18}$

Nos cálculos astronómicos e cronológicos intervêm frequentemente os nakșatras, a que se atribui por vezes uma extensão variável, consoante as dimensões da constelação correspondente, mais geralmente como divisões iguais do zodíaco, com uma extensão de $13^{\circ} 20^{\prime}$, subdividida em 4 pâdas ("pés, passos") de $3^{\circ} 20^{\prime}$ cada um. ${ }^{19}$ Como a velocidade da Lua na sua translação em torno da Terra não é uniforme, a ângulos iguais não correspondem tempos iguais, de modo que, mesmo quando se utiliza o nakșatra fixo de $13^{\circ}$ $20^{\prime}$, o tempo que a Lua demora a percorrê-lo varia entre um mínimo de 22 horas, 22 minutos e 24 segundos e um máximo de 26 horas, 32 minutos e 24 segundos, sendo a média de 24 horas, 17 minutos e 9,36 segundos. ${ }^{20}$ Torna-se assim indispensável o recurso a tábuas astronómicas.

Cada nakșatra corresponde a sua constelação vizinha do zodíaco ${ }^{21}$ e tem a sua divindade tutelar e seu símbolo. Assim o primeiro, chamado krttikâh (lit. "as entrançadas") corresponde à constelação das Plêiades ou Setestrelo, tem por divindade tutelar Agni, o deus do fogo, e por símbolo a navalha; o segundo, chamado rohinî (lit. "a vermelha", aludindo à tonalidade da estrela Aldebáran, $\alpha$ do Touro) corresponde às Híades, que fazem parte do Touro, tem por patrono Prajâpati, "o senhor das criaturas", e por símbolo o carrinho de mão; e assim por diante. Os nomes dos restantes 26 nakșatras - de que, como veremos, derivam os nomes dos meses na maioria dos calendários da Índia - variam ligeiramente de texto para texto; os mais comummente utilizados são os seguintes: $3^{\circ}$, mrgaçiras ou mrgaçîrșa ("cabeça de cervo", a $\lambda$ da Orion); $4^{\circ}$, ârdrâ ("a húmida", Betelgeuse, $\alpha$ da Orion); $5^{\circ}$, punarvasû ("as que tornam as coisas boas de novo", os Gémeos); $6^{\circ}$, pusya ("florescente", $\gamma$ e $\delta$ do Câncer) ou tișya; $7^{\circ}$, âçesâh ("as circundantes", $\alpha$ do Câncer e parte da Hidra); $8^{\circ}$, maghâh ("as generosas", Régulus, $\alpha$, e outras do Leão); $9^{\circ}$, pûrva-phalgunî ("a cinzenta anterior", $\delta$ e $\theta$ do Leão); $10^{\circ}$, uttara-phalgunî ("a cinzenta posterior", $\beta$ e outras do Leão); 11ํ, hasta, ("mão", cinco estrelas do Corvo); $12^{\circ}$, citrâ ("pintada, multicolor", a Espiga, $\alpha$ da Virgem); $13^{\circ}$, svâti ou niștyâ ("?" , Arcturus, $\alpha$ do Boieiro); $14^{\circ}$, viçâkhe ("de dois ramos", $\alpha$ e $\beta$ da Balança); $15^{\circ}$, anurâdhâh ("as favoráveis", $\beta$ e $\delta$ do Escorpião); $16^{\circ}$, jyeșthá (abreviação de jyeșthaghnî, "a que mata o mais velho", Antares, $\alpha$ do Escorpião); 17º , mûla ("abreviação de mûlabarhaṇ̂i, "a que desenraíza", $\varepsilon$ do Escorpião) ou vicrtau ("os dois que soltam"); 18, pûrvâsââhâh ("as invencíveis anteriores", $\delta$ e $\varepsilon$ do Sagitário); 19², uttarâṣâdhâh ("as invencíveis posteriores" ๔e $\zeta$ do Sagitário); $20^{\circ}$, abhijit ("a vitoriosa", a Vega, $\alpha$, e outras da Lira); $21^{\circ}$, çravana ("a <vaca> paralítica" $\alpha, \beta$ e $\gamma$ da Águia); $22^{\circ}$, çravișțhâh, ("as mais gloriosas", $\alpha, \beta, \gamma$ e $\delta$ do Golfinho), mais tarde ditas danișțhâh ("as mais ricas"); $23^{\circ}$, çatabhiṣa ("a que tem cem médicos", $\lambda$ do Aquário); $24^{\circ}$, pûrva- 
proșthapadâh, mais tarde pûrva-bhadrapadâh ("as de pés auspiciosos anteriores", $\alpha$ e $\beta$ do Pégaso); $25^{\circ}$, uttara-proșthapâdâh, mais tarde uttara-bhadrapadâh ("as de pés auspiciosos posteriores", $\gamma$ do Pégaso e $\alpha$ da Andrómeda); $26^{\circ}$, revatî ("a rica", $\zeta$ dos Peixes); $27^{\circ}$, açvayukau ("os dois atreladores de cavalos", $\beta$ e $\zeta$ do Carneiro); e $28^{\circ}$, bharanyah, ("as que levam", $\alpha, \beta$ e $\gamma$ da Mosca).

Novas precisões nos aparecem no Jyotișavedânga ou "apêndice astronómico do Veda", breve tratado de astronomia de que existem duas versões diferentes, uma em 43 çlokas (versos formados de dois dísticos de 16 sílabas) em apêndice ao Yajurveda, outra em 36 apensa ao Rgveda. ${ }^{22} \mathrm{O}$ tratado baseia-se no ciclo (yuga) quinquenal que conhecemos já, que se diz ter começado num momento em que o solstício do inverno se situava na constelação do Golfinho, o que se verificou em 1350 A. C.; mas isso não significa necessariamente que o tratado remonte a uma época tão recuada, datando provavelmente de meados do primeiro milénio A.C. ${ }^{23}$ A mais importante das novas noções com que aí topamos é a de tithi ou "dia lunar", unidade de tempo frequentemente usada tanto em astrologia como na datação de inscrições, ${ }^{24}$ que se pode definir como a trigésima parte de uma lunação, ou, em outros termos, o tempo que, após uma conjunção com o Sol (em sânscrito amâvâsyâ, lit. "coabitação"), ou seja uma lua-nova, a Lua demora a afastar-se deste $12^{\circ}$ sobre o zodíaco. A duração média do tithi é de 23 horas, 37 minutos e 28,092 segundos, mas nas datações usa-se geralmente a duração real do tithi, extraída das tabelas fornecidas pelos siddhântas ou tratados de astronomia, e não a sua duração média. A duração real varia entre um mínimo de 21 horas, 34 minutos e 24 segundos e um máximo de 26 horas, 6 minutos e 24 segundos; a variabilidade resulta de os movimentos do Sol e da Lua não serem uniformes, sendo mais rápidos no perigeu e mais lentos no apogeu. ${ }^{25}$

Para a medição em tempo de cada tithi não se usavam na Índia antiga as unidades de tempo dos caldeus de que usamos ainda hoje (horas, minutos e segundos), mas estranhas unidades de tempo como o muhûrta, equivalente a um trigésimo do dia solar (48 minutos), a nâdikâ, equivalente a meio muhûrta (portanto, 24 minutos), por sua vez correspondente a 10 1/20 kalâs, subdividindo-se a kalâ em 124 kâșthâs e por seu turno a kâsțthâ em cinco akșaras. $\mathrm{O}$ dia tem assim a bizarra conta de 603 kalâs, ou, segundo uma outra subdivisão, 124 lavas. Ao que parece estas subdivisões foram adoptadas por medirem ao mesmo tempo o dia solar, o dia sideral e o tithi ("dia lunar"), correspondentes respectivamente a 126, 124 e 122 lavas; o dia sideral ${ }^{26}$ equivale, por outro lado, a 549 kalâs, ao passo que a permanência média da Lua em cada nakșatra é de 610 kalâs. ${ }^{27}$ Uma outra subdivisão, sexagesimal e por consequência menos astronómica mas mais aritmética, subdivide a ghațikâ, equivalente à nâdicâa (igual, por conseguinte, a 24 minutos) em 60 palas, o pala (equivalente, portanto, a 24 segundos) em 60 vipalas (que assim duram 0,4 segundos cada um), e o vipala em 60 prativipalas (do valor de 0,006 de segundo); considera-se ainda a existência do prâna ("respiração") equivalente a 10 vipalas, portanto a 4 segundos.

O dia civil - que no ambiente religioso e clerical da civilização bramânica melhor se chamaria "dia ritual" - é designado por sâvana dina, isto é, dia (dina) em que se fazem os três savanas (libações de soma ou ambrosia), da manhã, do meio-dia e da tarde. Usa-se também o adjectivo sâvana para designar as outras unidades de tempo solar (mês, ano, etc.). Pela mesma razão por que a duração real do tithi não é uniforme ( $2^{\mathrm{a}}$ lei de Kepler) a duração do sâvana dina ou nictémero civil, geralmente medido de nascer do Sol a nascer. do Sol, tampouco o é, sendo maior no perigeu que no apogeu. É provavelmente por essa razão que os textos sugerem a utilização de uma outra unidade de tempo para além do dia civil, do dia sideral e do "dia lunar" ou tithi: o "dia solar" (saura dina ou arka dina), definido 
como $1 / 360$ do ano, o que não corresponde a nenhum evento astronómico preciso, mas ao tempo gasto em média pelo Sol para avançar um grau sobre a eclíptica. ${ }^{28}$ Seja como for o yuga ou período de cinco anos que constitui a base do calendário vêdico corresponde a 5 revoluções do Sol, 62 revoluções sinódicas da Lua, 67 revoluções siderais da Lua, 1800 "dias solares", 1830 dias civis (sâvana), 1835 dias siderais e 1860 tithis ou "dias lunares".

\section{A época clássica: os pressupostos astronómicos}

É possível que já ao tempo em que foi redigido o Jyotișavedânga a astronomia indiana tivesse recebido influências ocidentais, provindas de Babilónia. Com efeito, a duração do dia natural (isto é, o tempo que decorre entre o nascer e o pôr do Sol), que como é do domínio comum varia com as estações do ano, é ali dita variar entre 12 e 18 muhûrtas, o que, como um muhûrta corresponde no nosso sistema a 48 minutos, equivale respectivamente a 9 horas e 36 minutos e 14 horas e 24 minutos. Tais limites são, um e outro, precisamente observáveis a uma latitude de $35^{\circ} 24^{\prime}$, que é a do extremo norte do Caxemira, ${ }^{29}$ por conseguinte, a não ser que resultem de uma estimativa grosseira, ou as observações foram feitas aí, ou resultam da adopção de dados observados no Irão ou na Alta Mesopotâmia, que o autor do tratado aceitou acriticamente, sem se dar conta que se não aplicavam na quase totalidade da Índia.

18 Seja como for, após a fundação do Império Persa e da unificação do Irão por Ciro (559-529 A. C.) intensificaram-se os contactos entre a Índia e o Ocidente, o que permitiu o influxo das ideias astronómicas dos caldeus e, um pouco mais tarde, dos gregos - estas sobretudo a partir da conquista do noroeste da Índia por Alexandre Magno em 326 A. C. A Índia, desde sempre muito mais ligada ao Ocidente que ao Oriente, beneficiou assim dos progressos que a astronomia fez no mundo mediterrânico, do mesmo modo que este beneficiou dos avanços do pensamento indiano no domínio da matemática, nomeadamente a invenção do zero e a das funções trigonométricas. É nítido o contraste com a China que, à parte algumas influências da ciência indiana introduzidas com o budismo nos primeiros séculos da nossa era, apenas veio a ter conhecimento da astronomia ocidental no século XVII, através dos jesuítas.

As influências da astronomia helenística tornam-se nítidas nos tratados de astronomia indiana da época clássica, chamados siddhântas, palavra que literalmente significa "perfeição acabada, última perfeição". ${ }^{30}$ Há notícia da existência de cinco siddhântas, mas apenas um deles, o Saurasiddhânta ou Sûryasiddhânta chegou até nós na integridade do seu texto; os outros apenas nos são conhecidos através do comentário de Varâhamihira, na sua Pañcasiddhântikâ, que data de começos do século VI, e do resumo que deles dá A1Bîrûnî século XI. Os dois primeiros, o Paitâmahasiddhânta e o Vâsiștha-siddhânta, trazem ainda pouca novidade: o primeiro pouco se afasta do Jyotișavedânga, de que reproduz o ciclo quinquenal; as principais inovações do segundo são dar já as coordenadas de algumas estrelas em vez de as distribuir simplesmente pelos nakșatras, calcular a revolução sinódica de Mercúrio, Vénus, Marte, Júpiter e Saturno, e introduzir a divisão do zodíaco em doze signos. Os dois seguintes, o Pauliçasiddhânta e o Romakasiddhânta, são adaptações de obras helenísticas, devida a primeira, segundo Al-Bîrûnî, a Paulo de Alexandria, atribuída a segunda a um astrónomo indiano, Çrîsena, que provavelmente se limitou a refundir um tratado de origem romana, de onde o nome por que ficou conhecido, que significa simplesmente "siddhânta dos romanos"; como meridiano de 
referência usa o de Yavanapura, "cidade dos gregos" que é provavelmente Alexandria, ou então Constantinopla.

o Pauliçasiddhânta é o primeiro a dar uma fórmula trigonométrica para determinação da duração do dia natural em função da latitude do lugar e da declinação do Sol no dia em causa; revela também conhecimento da anomalia ${ }^{31}$ dos planetas, da equação do centro ${ }^{32} \mathrm{e}$ da paralaxe ${ }^{33}$ da Lua; dá regras para a predição dos eclipses, mas apenas aproximativas. ${ }^{34}$ O Romakasiddhânta introduz o conceito de revolução anomalística ${ }^{35}$ do Sol e da Lua, ao lado dos de revolução sinódica e revolução sideral, já contemplados pelo Jyotișavedânga. É provavelmente com eles que entram no sânscrito alguns préstamos vocabulares helénicos, como hora, "hora, horóscopo", kendra (de kentron, "centro" pronunciado à bizantina, utilizado para designar a anomalia de um planeta), liptâ (do grego leptón, "minuto"), apoklima, "inclinação", jyâmitra (de diámetron, "diâmetro"), etc.

21 Do ponto de vista que aqui nos mais interessa, que é o do calendário, as inovações mais significativas são a adopção da semana e a dos doze signos do zodíaco, cujos nomes são em sânscrito tradução dos nomes gregos. Os dias da semana têm assim os nomes das divindades indianas epónimas dos sete astros do sistema solar que lhes dão o nome, grosso modo correspondentes às divindades romanas ou germânicas que os designam na maior parte das línguas modernas da Europa: dia do Sol, dia da Lua, dia de Marte, e assim por diante. Em sânscrito esses nomes podem aparecer sob diversas formas, pela simples razão que a mesma divindade dá por diversos nomes ou epítetos: assim o domingo (Solis dies) é designado por Âdivâra, Âdityavâra, Ravivâra, Ahaskaravâra, Arkavâra, Arunavâra, Bhatțârakavâra, Aharpativâra, Bradhnavâra, Bhânuvâra, etc.; a segunda-feira (Lunae dies) por Induvâra, Somavâra, etc.; a terça-feira (Martis dies) quase sempre por Mangalavâra, por vezes por Âgârakavâra, Bhaumavâra, etc.; a quarta-feira (Mercurii dies) por Budhavâra, ${ }^{36}$ Baudhavâra, Saumyavâra ou Rauhineyavâra; a quinta-feira (Jovis dies) por Guruvâra, Bṛhaspativâra, Angirasavâra, etc.; a sexta-feira (Veneris dies) por Bhṛguvâra, Çukravâra, etc; e o sábado (Saturni dies) por Çanivâra, Saurivâra ou Mandavâra. O elemento vâra que figura em todos estes nomes significa etimologicamente "vez, volta". Daí vêm os nomes dos dias da semana nas línguas modernas da Índia. Por exemplo em concanim - língua do Concão, a faixa costeira entre os Gates e o mar, em torno de Goa, falada igualmente por algumas populações a sul até Mangalor - os nomes são os seguintes: Aitar, Somar, Mongllar, Budvar, Brestar, Sukrar e Sonvar.

O mesmo se passa, mutatis mutandis, com os doze signos do zodíaco, que têm os mesmos nomes que entre nós: Meșa, "carneiro", Vrșabha, "touro", Mithuna, "par, parelha, i. e., gémeos", Karkața, "câncer, caranguejo", Simha, "leão", Kanyâ, "moça, virgem", Tulâ, "balança", Vrçcika, "escorpião", Dhanus, "arco, i. e., Sagitário", Makara, "monstro marinho" (i. e., capricórnio), Kumbha, "jarra, bilha, i. e., aquário", Mîna, "peixe".

23 Um outro provável traço de influência da astronomia helenística que se descobre no Romakasiddhânta é o uso de um yuga ou ciclo de 2850 anos luni-solares de que 1050 são embolísmicos, isto é, contêm um mês suplementar, o que permite ajustar o ano lunar de 12 lunações sinódicas $(12 \times 291 / 2=354$ dias $)$ ao ano solar de 365 dias. Com efeito $2850=$ 150 x 19, e 19 anos solares correspondem a 235 revoluções sinódicas da Lua, o que permite pôr o ano lunar de acordo com o solar num ciclo de 19 anos: é o famoso ciclo de Méton, descoberto pelo astrónomo ateniense desse nome em $432 \mathrm{~A}$. C., e ainda hoje utilizado no cômputo eclesiástico para calcular a data da Páscoa, celebrada, como é sabido, no primeiro domingo após a primeira lua-cheia da primavera. 
24 Noutros aspectos, porém, estes siddhântas de origem helenística apartam-se dos seus modelos ocidentais, o que mostra que no decurso dos séculos foram retrabalhados e corrigidos, chegando eventualmente a resultados mais precisos que os da astronomia grega: ao ano trópico é assim atribuída uma duração de 365 dias, 5 horas, 55 minutos e 12 segundos, contra os 365 dias, 5 horas, 55 minutos e 15,8 segundos de Hiparco e Ptolomeu; e ao mês sinódico 29 dias, 12 horas, 44 minutos e 2,2 segundos contra os 29 dias, 12 horas, 44 minutos e 2,5 segundos dos astrónomos gregos.

o Sûryasiddhânta é considerado o mais rigoroso dos siddhântas, e é certamente por isso que é apresentado como uma revelação feita pelo próprio Sol a Maya, um asura (espírito maligno) que o invocara; segundo alguns dos manuscritos da obra, como Maya não podia suportar o ardor do Sol e este se não podia deter no seu curso para o ensinar, recomendou-lhe que se dirigisse a Romaka (i. e., a Roma), prometendo que aí se encarnaria em mleccha ("bárbaro") para então o instruir. Esta lenda dá conta da origem parcialmente ocidental da ciência astronómica que o tratado transmite. Apesar de algumas incoerências, os dados astrais que fornece permitem, datá-lo de meados do século IV da nossa era, ou, na pior das hipóteses, do século V. Compõe-se de 500 versos repartidos por catorze capítulos, e compreende nomeadamente uma tábua de senos, destinada ao cálculo do lugar verdadeiro de um planeta a partir da sua posição média, uma projecção gráfica dos eclipses e um estudo sobre o nascimento e ocaso helíaco ${ }^{37}$ dos planetas e das estrelas. As medidas das revoluções celestes constantes do Sûryasiddhânta são extremamente precisas: assim ao mês solar, cuja duração média é de 30,438030 dias é atribuída uma duração de 30,438229707 dias; ao mês lunar, que dura em média 29,530588 dias, uma duração média 29,530587946; e assim por diante.

O traço mais notável do Sûryasiddhânta é, sem dúvida, o facto de pela primeira vez na Índia assinalar o fenómeno da precessão dos equinócios, designado em sânscrito por krântipâtagati. ${ }^{38}$ Este fora descoberto no Ocidente por Hiparco (c. 190-125 A. C.), ao comparar as suas próprias observações astronómicas com as de Timócaris, feitas entre 295 e 272 A. C. em Alexandria. A descoberta da precessão dos equinócios parece ter sido feita independentemente na Índia, pois, por um lado, o valor anual que se lhe atribui, dito ayanâmça $a^{39}(54 ")$, está mais próximo da realidade $(50 ", 26)$ do que lhe atribuía Hiparco (36" ao ano); mas, por outro lado, é incorrectamente interpretado como um movimento de oscilação ou libração, quando na realidade se trata de um movimento secular ou contínuo, sempre no mesmo sentido. 0 erro provém, aparentemente, do desconhecimento da data em que foram compostos os Vedas, os brâhmanas (tratados rituais que os comentam) e o Jyotișavedânga, que atribuem coordenadas siderais diferentes ao ponto vernal; imaginando que o Jyotișavedânga era mais antigo do que os brâhmanas, o autor do Sûryasiddhânta foi levado a admitir que o ponto vernal se deslocava para trás e para diante, quando na realidade percorre a eclíptica sempre no mesmo sentido.

28 Assim, em virtude da precessão dos equinócios, o ponto vernal não se situa já hoje, como no tempo de Hiparco, no ponto em que o Sol entrava no signo do Carneiro, mas $28^{\circ}$ mais atrás, praticamente à sua entrada na constelação dos Peixes. A astrologia ocidental continua, porém, a atribuir à entrada do Sol nos diferentes signos as datas que lhes assinavam os astrónomos helenísticos, sem ter em conta que se encontram hoje cerca de um mês atrasadas. Se alguma vez esteve certa, está, pois, hoje manifestamente errada. É pela mesma razão que continuamos a celebrar a 25 de Dezembro e mesmo a 6 de Janeiro festas que representam a cristianização da do nascimento do Sol Invictus, coincidente com o solstício do inverno, quando na realidade o solstício se situa em nossos dias por 22 de 
Dezembro. A astrologia indiana, ao invés, faz muitas vezes a correcção, distinguindo o cálculo sâyana ("com movimento"), que acompanha o movimento da eclíptica e do ponto vernal, e por conseguinte o ano trópico, do cálculo nirayaṇa ("sem movimento"), que se reporta às estrelas e ao ano sideral - o que acarreta uma dor de cabeça suplementar para o decifrador de inscrições, onde nem sempre se especifica se a efeméride astronómica indicada é sâyana ou nirayaṇa...

Um outro aspecto em que o Sûryasiddhânta apresenta interesse é a definição astronómica dos grandes ciclos da involução do mundo caros à cosmologia hindu - de que se encontra uma bela epítome no Viṣnupurâna, tratado de mitologia salpicado de precisões astronómicas ${ }^{40} \mathrm{~A}$ duração atribuída a esses ciclos é, em parte, resultado do desejo de harmonizar entre si as diversas unidades astronómicas, de que constituem o menor múltiplo comum, em parte fruto de especulações numerológicas do tipo das dos pitagóricos. Seja como for, essas divisões fizeram escola, encontram-se em numerosos purânas e usam-se, por vezes, até nas inscrições para definir datas. Demos a palavra ao Vișnupurâna: ${ }^{41}$

...30 muhûrttas constituem um dia e uma noute dos mortais; 30 desses dias fazem um mês, dividido em 2 quinzenas; 6 meses formam um ayana ["movimento" do Sol, num semestre ao norte, noutro ao sul do equador] e 2 ayanas formam um ano. 0 ayana meridional é a noite e o setentrional o dia para os deuses. 12.000 anos divinos (divyavarsia), compostos de [366 de] esses dias, constituem o caturyuga [período de quatro yugas, também chamado mahâyuga, "grande yuga"], ou período de quatro idades. São assim distribuídas: a idade Krta [lit. "<bem> feita, perfeita", i. e. a Idade de Ouro] tem 4.000 anos divinos; a Tretâ ["terno (de dado), tríada", a Idade de Prata], 3.000; a idade Dvâpara ["duque", a Idade de Bronze], 2.000 e a Kali [lit. "ás", a Idade de Ferro ou das Trevas em que vivemos] 1.000; assim o declararam os práticos nas cousas antigas. O período que precede um yuga é chamado um sandhyâ [lit. "momento de transição, crepúsculo"] e é de tantas centenas de anos quantos milhares possua o yuga; e o período que se segue a um yuga é chamado sandhyâmsa [lit. "que traz à espádua o crepúsculo"] e tem idêntica duração. $O$ intervalo entre o sandhyâ e o sandhyâmisa é o yuga, chamado Krta, Tretâ, etc. O Krta, a Tretâ, o Dvâpara e o Kali juntos constituem uma "grande idade" (mahâyuga) ou conjunto de quatro idades; um milhar de tais conjuntos é um dia de Brahmâ, e 14 Manus [lit. "homens <primordiais>", "Adões") reinam durante ele.

Estamos, por conseguinte, diante não só de um conceito de tempo cíclico como de uma visão regressiva da História, baseada na ideia de gradual recessão do dharma ou ordem moral, idêntica à teoria das quatro idades entre Gregos e Romanos, belamente expressa nas Metamorfoses de Ovídio. A atribuição de durações decrescentes aos quatro yugas corresponde a uma ideia de aceleração do curso da História, que só não corresponde à das modernas concepções historiográficas porque assenta num conceito de tempo regressivo e não na ideia de progresso. $O$ início do kaliyuga ou idade de trevas em que vivemos é geralmente identificado com o momento da morte de Crixna (Krșnna), a delTadeira encarnação de Vixnu antes de Kalki, o avatâra escatológico que porá fim ao kaliyuga e com ele a todo um ciclo de existência do mundo.

31 Como o Vișnupurâna, o Sûryasiddhânta atribui ao caturyuga ou mahâyuga a duração de 12.000 anos divinos, correspondentes a 4.320 .000 anos solares humanos, ou seja, quatro vezes 1.080.000 anos, o mais curto período que contém um número inteiro de anos solares, calculados à razão de 365 dias, 6 horas, 12 minutos, e 35,556 segundos. 1.080 .000 representa, por outro lado, o produto dos 30 muhûrtas contidos num dia pelos 360 dias do ano vêdico; por outro lado ainda, é cem vezes o cêntuplo de 108, número particularmente 
caro à especulação numerológica tanto de hindus como de budistas, pois corresponde ao produto de 4 , número das fases da lua, por 27 , número de dias contido numa revolução sideral da lua (e daí, número dos nakṣatras existentes). Atribuía-se igualmente à suposta libração do ponto vernal uma amplitude total de $108^{\circ}$, ou seja, 54" para cada lado. Por sua vez, 4.320.00 anos é, ao mesmo tempo, o quádruplo do período de 1.080 .000 anos e o produto de 12.000 anos divinos por 360 .

Os purânas e a literatura afim consideram ainda a existência de múltiplos do caturyuga, como o kalpa ou "dia de Brahmâ", que dura mil caturyugas e corresponde ao período de existência do mundo, da criação à destruição final; cada "dia de Brahmâ" é seguido de um período igual de inexistência do mundo, correspondente à "noite de Brahmâ". Por seu turno esses "dias de Brahmâ" compõem um "ano de Brahmâ", durando a existência desse deus cem de tais anos, ou seja, 311.000 biliões de anos humanos, reputados a mais elevada duração que se pode conceber.

o que mais importa, porém, ter em atenção é que o Sûryasiddhânta data o início do Kaliyuga das 0 horas do dia 18 de Fevereiro de 3102 A. C., pois essa balisa é frequentemente utilizada na datação de inscrições e outros actos oficiais. Essa data é dita corresponder a um momento em que o Sol, a Lua e os outros cinco planetas, tal como no início dos outros yugas, estavam alinhados sobre o meridiano de Lankâ - mítica cidade de Ceilão suposta estar situada sobre o equador, mas de qualquer modo de longitude idêntica à de Avanti ou Ujjayini ( $75^{\circ} 51^{\prime} 45^{\prime \prime}$ E de Greenwich), cidade sita a $23^{\circ} 11^{\prime} 10^{\prime \prime} \mathrm{N}$, perto de Gwalior. As tabelas indianas dão, com efeito, normalmente as efemérides astronómicas em termos de tempo médio de Lañkâ.

Um outro ciclo, mais curto, que nos aparece pelo menos desde esta época, tem uma origem astronómica precisa: o ciclo joviano, de 12 anos, correspondente quase precisamente a uma revolução sideral de Júpiter, que dura 11 anos e 314,839 dias (ao passo que a sua revolução sinódica, medida entre duas conjunções com o Sol, dura apenas 398,88 dias). Há duas maneiras de o computar, paralelas às duas maneiras de determinar os nakșatras, os signos do zodíaco, etc: em termos de movimento médio, dividindo a revolução joviana em doze partes iguais, ou em termos de movimento real, tomando para início de cada ano do ciclo o nascimento helíaco de Júpiter; em ambos os casos tem de se ajustar ao ano solar mediante a adição ou supressão de anos do ciclo; mas cada siddhânta dá suas regras para regular a concordância. Descontadas tais diferenças, esse ciclo duodenário está para o ano terrestre como este está para o mês, de modo que, ao longo dele, Júpiter atravessa num ano os mesmos nakșatras que o Sol percorre num mês. É também usado na astrologia chinesa, que coloca cada um dos seus 12 anos na dependência de um animal tutelar. Na Îndia é por vezes utilizado nas datações, além de ditar o ritmo de certas peregrinações e festivais religiosos, como o Mâmângam, Mâmândạ, Mahâmakham ou Mahâmakhavêla - o principal festival hindu do Kêraḷa ou Malabar, celebrado durante 28 dias nas margens do Tirunâvây a cada doze anos e presidido pelo Samorim de Calecut.

Um ciclo mais aperfeiçoado, de 60 anos, correspondente a 5 revoluções siderais de Júpiter e, grosso modo, a duas de Saturno (de 29 anos e 1/2 cada uma), em uso desde o século VI, permite uma melhor concordância do ciclo joviano com o calendário solar. É o ciclo denominado brhaspatisamvatsaracakra, que comporta 5 "anos jovianos" (brhaspatisamvatsaras) de 361,026721 dias solares, correspondentes ao tempo que Júpiter gasta a percorrer 1/12 da sua órbita ou, em termos de movimento médio (abstraindo da sua aceleração no periélio e do seu retardamento no afélio), um signo do zodíaco. A 
revolução sideral de Júpiter corresponderia assim a 4.332,320652 dias, valor que o Sûryasiddhânta corrige para 4.332,41581277 dias, quando na realidade dura 4.332,589 dias solares médios.

Deixando de lado as concepções astronómicas dos jainas e as obras dos antigos astrólogos, de que o principal é Garga, acrescentaremos, para terminar esta panorâmica da evolução da astronomia e da cronologia dos indianos, uma breve referência aos astrónomos posteriores à redacção dos siddhântas ${ }^{42}$. Trata-se em geral de hindus ou de jainas, pois o budismo, interdizendo a astrologia, não estimulou o intesse pela astronomia. $O$ principal é o tratado de Âryabața ${ }^{43}$ que data provavelmente de 499 A. D. e compendia todas as aquisições do saber feitas até aí; expõe em detalhe a teoria dos epiciclos, criada, como vimos, para explicar a anomalia das órbitas do Sol, da Lua e dos vários planetas; sobretudo, é o primeiro a expor a ideia de rotação da Terra, que, aliás, achou poucos sequazes. A sua escola, chamada áryapakșa é especialmente prezada na Índia meridional. Varâhamihira ${ }^{44}$ que floresceu em meados do século VI, é sobretudo conhecido pela sua Pañcasiddhântikâ em que comenta os cinco siddhântas, acrescentando-lhes numerosas correcções pontuais chamadas bijas ("grãos"); o mesmo faz nos seus tratados de astrologia, a Bṛhatsamihitâ, a Yogayâtrâ, o Bṛhajjâtaka e o Laghujâtaka. Brahmagupta, ${ }^{45}$ nascido perto de Multân no Panjâb em 598, escreveu em 628 o seu Brâhmaspuțasiddhânta, em que procura refutar a teoria da rotação da Terra de Âryabața; embora Al-Bîrûnî o repute o maior dos astrónomos indianos, a sua obra tem mais interesse para a história da matemática que para a da astronomia. Seja como for a sua escola predomina no NW da Índia (Guzerate e Rajasthan). Quanto a Bhâskara, nascido em 1114, escreveu em 1150 o seu Siddhântaçiromaṇi que, como a obra precedente, tem mais interesse matemático que astronómico.

Nenhum destes autores teve influência na estrutura dos sistemas calendáricos da Índia, mas as suas tabelas astronómicas continuaram pelo tempo fora a ser utilizadas no cálculo dos tithis, nakșatras, lugares do Sol e da Lua, etc., e por isso há que tê-las em conta.

\section{A época clássica: os calendários}

Os almanaques indianos são designados por pañcânga, "de cinco membros", porque tradicionalmente fornecem para cada ano cinco elementos: os vâras ou dias da semana, os tithis ou "dias lunares", os nakșatras ou mansões da Lua, os yogas, ${ }^{46}$ momentos em que a soma dos movimentos do Sol e da Lua é igual à extensão de um nakșatra, e os karanas, correspondentes cada um a metade de um tithi. Os yogas são em número de 27 , tantos como os nakșatras, designados por outros tantos nomes próprios, que não vale a pena enumerar aqui. Os karaṇas, em número de 60 dão igualmente por um nome; há ao todo 11 nomes, mas o $1^{\circ}$ (kimstughna) é reservado ao primeiro karaṇa da lunação ao passo que os três últimos (çakuni, nâga e catuspada) são reservados aos três derradeiros $\left(58^{\circ}, 5^{\circ}\right.$ e $\left.60^{\circ}\right)$ karaṇas da lunação, sendo os restantes 7 nomes (bava, bhâlava, kaulava, taitila, gara, baniij e vịsti) atribuídos ciclicamente (como os dias da semana) aos demais karanas, do $2^{\circ}$ ao $57^{\circ}$. A divisão em karanas corresponde a uma subdivisão de cada tithi ou "dia lunar" numa espécie de "manhã" e "tarde"; oferece, por isso, pouco interesse, embora por vezes seja utilizada nas datações. Os almanaques dão também em geral indicações de interesse puramente astrológico, como os tyâjyas "[períodos] a abandonar", ocasiões nefastas em que não convém empreender o que quer que seja; muitas vezes dão também o número 
total de dias (dito dyugana ou ahargana, "série de dias") que decorreram desde o início do kaliyuga, igualmente importante em astrologia. e no Bengala; em Mangalor é apenas usado pelos brâmanes. 0 começo do ano é definido pela meșasamkrânti ou entrada do Sol no signo (râçi) do Carneiro (meșa), que tanto pode ser determinada pelo método nirayaṇa, não esguardando à precessão dos equinócios, como pelo sâyana, que a leva em conta; no primeiro caso toma-se a data da entrada real do Sol no signo do Carneiro (11 de Abril) como começo do ano, considerando ficticiamente que se dá nessa data o equinócio; no segundo caso torna-se o equinócio verdadeiro (21 de Março) como início do ano, convencionando-se, como no Ocidente, que se deu nessa data o meșasamkrânti ou entrada do Sol no signo do Carneiro, embora na realidade esteja então ainda bem dentro da constelação dos Peixes. O método nirayaṇa é mais usual. Os começos dos meses seguintes são definidos pelas outras samkrântis, ou seja, pela entrada (real ou convencional, consoante se use o sistema nirayana ou o sâyana) do Sol em cada um dos signos subsequentes. Aí surge, em qualquer dos casos, uma complicação suplementar: como a samkrânti, astronomicamente calculada, pode ocorrer a qualquer momento do dia ou da noite, mas o dia começa sempre ao nascer do Sol, há vários critérios para determinar qual é o dia 1 do mês solar em causa; em Orissa conta-se como dia 1 do mês aquele em que ocorre a samkrânti; no Bengala, quando a samkrânti tem lugar entre o nascer do Sol e a meia noite considera-se que o dia 1 é o seguinte, ao passo que se tem lugar entre a meia-noite e o nascer do Sol o dia 1 não é o dia seguinte mas o imediato; para os tâmules do Tamilnâdu e da região do Cabo Comorim, outrora dependente do reino de Travancor, o mês começa no dia da samkrânti se esta tem lugar entre o nascer e o pôr do Sol, no dia imediato se entre o pôr e o nascer do Sol; para os malabares ou malaialas do Kêraḷa, se a samkrânti ocorre durante os primeiros $3 / 5$ da metade diurna do dia civil (portanto até às $13 \mathrm{~h} 12 \mathrm{~m}$, na nossa maneira de contar o tempo) o mês começa nesse mesmo dia, no dia imediato se depois dessa hora. Uma terceira complicação resulta da desigualdade da rapidez do movimento do Sol sobre a eclíptica no perigeu e no apogeu; levando-a em conta, toma-se como início do mês a samkrânti verdadeira, uso predominante para fins religiosos; não a levando em conta, uma samikrânti convencional, correspondente à divisão do ano em doze partes iguais. A diferença entre uma samkrânti verdadeira e uma samikrânti média é designada por çodhya ("purificação, emenda, correcção") e varia, fraca mas constantemente, com o tempo, devido ao desfasamento entre o ano sideral e o ano anomalístico, ou, por outras palavras, ao retardamento do perigeu solar, que, como vimos, retrograda $21 ", 7$ por ano sobre a eclíptica. ${ }^{47}$

Os nomes dos meses vêdicos caíram de há muito em desuso; por isso, na época clássica e nos dias de hoje, quando se utiliza o calendário solar, designam-se os meses ou pelos nomes dos signos do zodíaco correspondentes (uso malaiala, o mais lógico e o mais simples), ou pelos dos meses lunares com que grosso modo coincidem, que, como adiantámos já e veremos melhor em seguida, derivam dos nomes dos nakșatras em que é suposto ter normalmente lugar o seu plenilúnio. Neste último caso há ainda a considerar 
dois usos diferentes: pelo costume tâmule, o mês solar toma o nome do primeiro mês lunar com que parcialmente coincide; pelo bengala, o do segundo.

42 A uniformidade não é maior nem menor a confusão nas regiões onde predomina o calendário luni-solar. 0 mês é geralmente dividido em duas quinzenas (pakșas, lit. "asas"), designadas uma por "quinzena clara" (çuklapakșa, sitapakșa ou çuddhapakșa), ou "primeira quinzena" (pûrvapakșa ou, abreviadamente, çudi, çuti ou sudi) correspondente aos períodos da lua-nova e quarto-crescente em que ao pôr do sol há luar; outra por "última quinzena" (aparapalkṣa) ou "quinzena escura" (krșnapakșa, asitapakșa, bahulapakșa, vadyapakșa ou, abreviadamente, vadi, vati ou badi) correspondente ao período da lua-cheia e quartominguante, em que a Lua nasce depois do pôr do sol e não há, por conseguinte, luar à boca da noite. No norte da Índia considera-se normalmente que o mês começa na lua-cheia (pûrnacandra, pûrṇamâsa ou pûrṇimâ), de modo que a quinzena escura precede a clara: é o uso chamado pûrṇimânta ("a acabar no plenilúnio") ou kṛ̦nnâdi ("com a <quinzena> escura ao começo"). No sul da Índia prevalece o costume oposto: o mês começa com a lua-nova, de modo que a quinzena clara precede a escura; é o uso chamado amânta (lit. "sem lua ao fim"), çuklâdi ("com a <quinzena> clara ao começo") ou darçânta ("com a aparição <da lua> ao fim"). Embora tenham geralmente os mesmos nomes, os meses do sul e do norte só coincidem na realidade durante a quinzena clara.

Conforme dissemos já, os meses tomam normalmente nomes derivados dos dos nakșatras em que se situam os respectivos plenilúnios. Como na lua-cheia o Sol e a Lua estão em oposição, esses nakșatras representam regiões do céu verticalmente opostas aos signos do zodíaco por onde na mesma época se passeia o Sol. Por outro lado existem 28 nakșatras no zodíaco, mas no mesmo ano solar não podem ocorrer mais do que 12 , no máximo 13 , plenilúnios; como a revolução sinódica da Lua, de que dependem as suas fases, não é divisível pela sua revolução sideral, que dita a sua viagem mensal pelos diferentes nakșatras, os plenilúnios podem, na realidade, ter lugar em qualquer destes. A escolha dos 12 nakșatras epónimos dos meses lunares é, assim, parcialmente convencional, escolhendo-se umas vezes o primeiro, outras o segundo dos dois (ou mesmo três) ${ }^{48}$ nakșatras em que naquele mês pode ocorrer o plenilúnio.

Seja como for, começando no equinócio da primavera, os nomes dos meses são em sânscrito os seguintes: Caitra, Vaiçâka, Jyaiștha, Âșaḍha, Çrâvana, Bhâdrapada, Âçvina, Kârttika, Márgaçîrșa, Paușa, Mâgha e Phâlguna, correspondentes, respectivemente, aos nomes do $12^{\circ}, 14^{\circ}, 16^{\circ}, 18^{\circ}-19^{\circ}, 21^{\circ}, 24^{\circ}-25^{\circ}, 27^{\circ}, 1^{\circ}, 3^{\circ}, 6^{\circ}, 8^{\circ}$ e $9^{\circ}-10^{\circ}$ nakșatras que enumerámos mais acima. Em bengali ou bengala têm formas derivadas destas: Coitro, Boiçâkho, Jyoiștho, etc. Em tâmul têm nomes em parte correspondentes, mas desfasados dos dos nakșatras, devido ao uso combinado do método sâyana e do estilo amânta: Pañguni, Çittirei, Veigâaçi, Âni, Âḍi, Âvaṇi, Purațtâç̧i, Eippaçi, Kârttigei, Mârgali, Tei e Mâçi. Em concanim, ainda que na prática raramente usados, pois o calendário gregoriano tende a prevalecer, há também nomes vernáculos, que apenas nalguns casos correspondem àqueles: Phoggu, Besso, Kartingoll, Atti, Sonno, Nirnall, Bantingoll, Jardo, Ferardo, Puintingoll, Mai e Suggi. ${ }^{49}$ Em malaiala os meses têm, como adiantámos já, os nomes dos signos do zodíaco correspondentes pelo método sâyana, que são: Mînam (Peixes), Meḍam (Carneiro), Eḍavam (Touro), Midunam (Gémeos), Karkadakam (Câncer), Cingam (Leão), Kanni (Virgem), Tulâm (Balança), Vŗ̣cikam (Escorpião), Dhanu (Sagitário), Makaram (Capricórnio) e Kumbham (Aquário).

Nas zonas em que se usam os meses lunares, os seus nomes são sempre os correspondentes aos nomes sânscritos que demos acima, derivados, como vimos, dos dos 
nakșatras. Se suceder haver dois novilúnios dentro do mesmo mês solar, há dois meses com o mesmo nome, dito um nija ("inato, genuíno") outro adhika ("ajuntado"); no sul este é intercalado antes daquele; no norte, de harmonia com o estilo pûrnimânta, no meio das duas quinzenas. Se, o que é mais raro, devido ao efeito comulativo das desigualdades da velocidade do movimento da Lua e da do Sol, ${ }^{50}$ não houver durante o mês solar nenhum novilúnio, esse mês é nesse ano suprimido (kșaya, lit. "destruído"). Pode usar-se a seguinte regra prática: se o mês solar começar e terminar durante quinzenas homónimas (claras ou escuras), o mês lunar epónimo é normal; se começar durante uma quinzena escura e terminar numa clara, há um mês intercalar; se começar numa clara e terminar numa escura, há supressão de um mês.

Os anos solares são geralmente conhecidos por meșâdi (lit. "com o começo no Carneiro"), os luni-solares por caitrâdi ("com o começo em Chaitra"); há contudo usos divergentes, mais raros, que não coincidem nem com um nem com outro dos dois sistemas, como o de começar o ano solar no signo da Virgem ou no do Leão.

Nas inscrições as datas não são geralmente contadas pelos dias do mês, mas pelos tithis, numerados de um a quinze dentro de cada quinzena, à excepção dos tithis das sizígias que têm nome próprio: paurnamâsi para o da lua-cheia, amâvâsî ou amâvâsyâa ${ }^{51}$ para o da luanova. Uma data pode, por consequência, apresentar-se sob a seguinte forma: Mâghaçuddhapañcamyâm, ou abreviadamente, Mâghasudi 5, que significa "5ำ tithi da quinzena clara do mês de Mâgha". Como o início dos tithis não coincide senão muito raramente com o nascer do sol, início do dia civil, os dias da quinzena recebem o número (ou nome) do tithi que termina no seu decurso. Como os tithis (sempre em consequência da bendita $2^{\mathrm{a}}$ lei de Kepler!) correspondem a distâncias angulares fixas e não a intervalos de tempo iguais, é imprescindível recorrer a tábuas astronómicas, ${ }^{52}$ de que as mais precisas dão o momento de início do tithi com uma aproximação de 24 segundos. Tal como se passa com os novilúnios e os meses solares, podem começar dois tithis no mesmo dia solar (o que sucede em média uma vez a cada 63 10/11 tithis) ou, muito mais raramente, não começar nenhum tithi durante o dia em causa; nesses casos procede-se como para os meses, isto é, insere-se, num caso, no mês um dia suplementar - designado por $n$ (número do dia precedente) seguido de adhika ou dvitîya, "bis" - e suprime-se, no caso oposto, um dia, considerado kșaya, "anulado".

Quanto à contagem dos anos, há que notar primeiramente que o seu começo não ocorre em toda a Índia na mesma ocasião. No norte o ano luni-solar civil começa, como em geral o ano astronómico, com a lua-nova do mês Chaitra, vizinha do equinócio da primavera; mas como no norte da Índia os meses começam na lua-cheia, segue-se que o ano-novo tem lugar a meio do mês, entre a sua quinzena escura e a sua quinzena clara. No sul tudo é, desta vez, mais simples: o ano começa sete meses mais tarde, ao mesmo tempo que o mês, com a lua-nova de Kârttika, coincidindo assim com a popular festa das luzes ou divali.

Na maneira de contar os anos não há tampouco uniformidade, pois coexistem dois estilos: ou contar por anos expirados, ditos gata, "idos" (o que pressupõe a existência de um ano 0 , qualquer que seja a era adoptada), costume mais corrente, adoptado nas tabelas astronómicas; ou contar pelo ano em curso, dito vartamâna, "corrente", como fazemos na Europa com a era de Cristo, que começou no ano 1.

50 As eras adoptadas são, como adiantámos já, assaz diversas. ${ }^{53}$ Mencionaremos apenas os usos mais correntes ou mais curiosos. Os anos podem computar-se simplesmente pelo kaliyuga, que como vimos, é suposto ter começado a 18 de Fevereiro de $3102 \mathrm{~A}$. C. Podem também computar-se pelos ciclos duodenário e sexagenário de Júpiter, em que os anos 
são designados por nomes e não por números. Se se utiliza o ciclo duodenário dão-se aos vários anos os nomes dos doze signos do zodíaco, consoante o signo em que Júpiter se encontre no ano em causa, ou os dos doze meses precedidos de mahâ, que significa "grande": mahâcaitra, mahâvaiçâka, etc.

No ciclo sexagenário os nomes são os seguintes: $1^{\circ}$, prabhava ("fonte, origem"); $2^{\circ}$, vibhava ("potência, soberania"); 3º, çukla ("brilho, brancura"); 4, pramoda ("gáudio imenso"); $5^{\circ}$, prajâpati ("senhor das criaturas"); 6º angiras (nome de um antigo rși, ou asceta autor de hinos vêdicos, e do planeta Júpiter); $7^{\circ}$, çrîmukha ("de bela face"); $8^{\circ}$, bhâva ("existência");

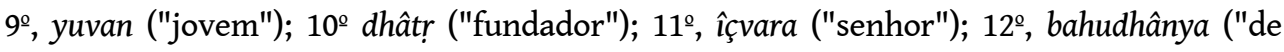
muito grão"); 13ำ, pramâthin ("destruidor", nome de um râkșasa ou demónio); 14ํ, vikrama ("heroísmo"); 15º vrșa ("touro"); 16으, citrabhânu ("de brilho multicolor", epíteto do fogo); 17², subhânu ("que brilha ao longe"); $18^{\circ}$, târaṇa ("que livra de dificuldades, salvador"); $19^{\circ}$, pârthiva ("senhor da terra"); 20ㅡ, vyaya ("transitório", nome de um Nâga, semi-deus semelhante a uma serpente); $21^{\circ}$, sarvajit ("vencedor de tudo"); $22^{\circ}$, sarvadhârin ("que segura tudo"); $23^{\circ}$ virodhin ("conflituoso, adversário"); $24^{\circ}$ vikrta ("alterado, disforme"); 25, khara ("duro, rude"); $26^{\circ}$, nandana ("que alegra ou faz feliz", epíteto de Vixnu e Xiva); 27², vijaya ("conquista, vitória"); $28^{\circ}$, jaya ("vitória", epíteto do Sol); 29ํ, manmatha ("amor carnal, paixão"); 30², durmukha ("de má cara", nome de um demónio-serpente); 31,

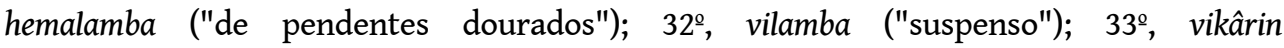
("inconstante, variável"); 34², çârvarin ("nocturno, tenebroso"); 35², plava ("flutuante"); $36^{\circ}$, çubhakrirt ("de bom agoiro, que traz felicidade"); 37º, çobhana ("belo, excelente"); $38^{\circ}$, krodhin ("irado, encolerizado"); 39, viçvâvasu ("bom para o mundo", epíteto de Vixnu);

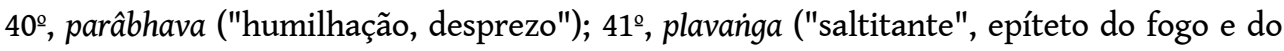

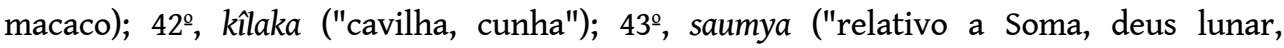

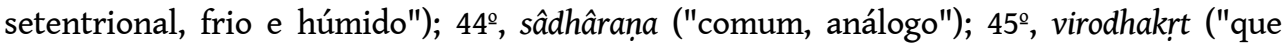
causa hostilidade"); 46으, paridhâvin ("que corre em torno"); 47º, pramâdin ("negligente");

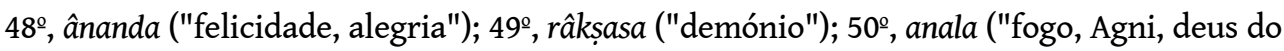

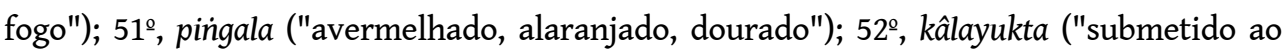

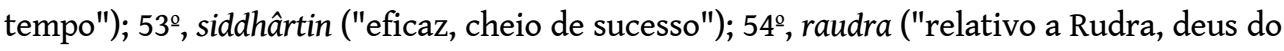

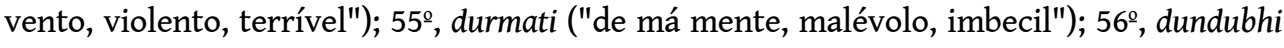
("tambor", nome de um râkșasa ou demónio e de um yakșa, génio ao serviço de Kubera,

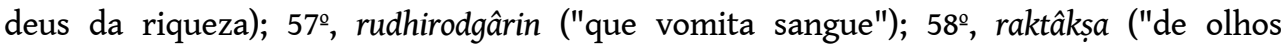
vermelhos"); 59², krodhana ("irascível, irritável"); e 60 akșaya ("imperecível"). Ter-se-á notado que dos nomes uns são auspiciosos, outros de mau agoiro.

Neste sistema, como a revolução sinódica de Júpiter (o período que medeia entre duas conjunções de Júpiter com o Sol), denominada bârhaspatyasamivatsara ou "ano joviano", demora menos 4,232 dias que o ano solar (o que perfaz uma diferença de 1 ano em c. 86), há que proceder a acertos semelhantes aos que se fazem para harmonizar o mês lunar com o ano solar; obtém-se esse efeito saltando um ano do ciclo sempre que dentro do mesmo ano solar caiam os inícios de dois bârhaspatyasamvatsaras consecutivos. 0 início dos ciclos sexagenários é fixado em diversas datas, consoante as regiões da Índia e as tabelas astronómicas utilizadas; uma tradição do país tâmul situava-o no ano correspondente a 427 A. D., enquanto que no país telugu (o actual estado de Andhrapradesh) o faziam começar 14 anos antes do kaliyuga, portanto em 3116 A. C. De qualquer modo no sul da Índia os acertos com o ano solar deixaram de ser praticados em 909 da nossa era, ano em que se deveria ter suprimido mas não se suprimiu um bârhaspatyasamvatsara; a partir de aí o ciclo tornou-se convencional, reduzido a um 
sistema de nomenclatura dos anos, sem correspondência astronómica. Em compensação aparece aí em uso no século XVIII (sobretudo em Madurai) um ciclo de 90 anos solares, cujas origens são mal conhecidas.

Uma era aparentada ao kaliyuga pelas suas origens míticas, mas desprovida de significação astronómica, é a dos Sete Rexis (saptarșikâla), do Mundo (lokakâla ou laukikakâla) ou dos Livros [Santos] (çâstrakâla), usada no Caxemira e no Panjâb na época de Al-Bîrûnî; começa em 3076 A. C., conta por anos correntes (vartamâna) e usa os estilos caitrâdi e purnimânta.

A era do Nirvana de Buda, que começa em 543 A. C., caiu em desuso na Índia, mas usa-se em Ceilão e nos países budistas da Península Indochinesa. Os Jainas usam, semelhantemente, a era da morte do Jina, fundador da seita, em 527 A. C.

As duas eras mais correntes na Índia e nos países indianizados do Sueste Asiático são a de Vikrama e, sobretudo, a dos Çakas. A primeira, usada um pouco por toda a parte, mas sobretudo no centro e no oeste da Índia, conta os anos a partir do reinado do rei Vikramâditya, herói de um ciclo de lendas comparável aos de Alexandre e do Rei Artur no Ocidente; inicia-se no ano 57 da era cristã, conta geralmente por anos expirados e usa no norte os estilos caitrâdi e purnimânta, no sul o kârttikâdi e o amânta. A segunda data do estabelecimento dos mahâkșâtrapas ou "grandes sátrapas" Çakas (Citas, ou seja, indoeuropeus nómadas do grupo iraniano, assaz persianizados) na zona do Guzerate e do Mahârâshtra, e inicia-se em 78 da nossa era. Conta geralmente por anos expirados, solares (meșâdi) ou luni-solares (caitrâdi), seguindo no norte o estilo purnimânta, no sul o amânta. Os cronistas portugueses como Diogo do Couto conhecem a sua existência, mas nem sempre sabem convertê-la correctamente à era cristã. Levada com a influência indiana para a Península Indochinesa e para a Insulíndia, é ainda hoje utilizada em Java, mas com a seguinte particularidade: até 1625 A. D. contou-se, como na Índia, por anos luni-solares, com inserção periódica de um mês suplementar para restabelecer a correspondência com o ano solar; desde essa data, por decreto de Sultan Agung de Mataram, adoptou-se o uso muçulmano, abolindo-se os anos embolísmicos e contando-se sempre o ano a 354 dias, o que obriga a recorrer ao uso de tabelas que dêem em cada caso a era e a data do ano-novo. 54

Outras eras de origem política tiveram vida mais efémera: assim a era dos Guptas, que começa a contagem dos anos com o advento dessa dinastia em 319 A. D., usada na Índia central e no Nepal até ao século XIII; a de Harșa, datada da subida desse rei ao trono em 606 A. D., usada no seu império (Índia setentrional, século VII) e também no Nepal; a era dos Câlukyas orientais, inaugurada em 1075 e abandonada em 1162; a era marata, fundada por Xivaji (Çivaji) em 1673 e logo caída em desuso; etc.

Uma era bastas vezes referida pelos nossos antigos cronistas é a "era de Coulão", que começa em 824-825 A. D. e parece corresponder à data da fundação da cidade ou da sagração de um templo de Xiva que aí existiu. Localmente é muitas vezes designada por era de Paraxuráma (Paraçurâma), uma encarnação de Vixnu a quem é atribuída a secagem de toda a faixa litoral de Mangalor para o sul, e para leste até aos Gates, e portanto as origens do Quêrala ou Malabar, assim retirado das águas. Outras vezes tradição reportada por exemplo por Duarte Barbosa - identifica-se o seu ponto de partida com a divisão do Malabar em pequenos reinos pelo último rei Chêra, Cêramân Perumâl. Segundo essa lenda - criada quiçá para disfarçar a derrota do último mahârâja ou "grande rei" da dinastia Chera (Cêram) pela dinastia Chola (Côlam) do Tamilnâḍü, no século X da nossa era - Cêramân Perumâl teria voluntariamente abdicado, dividindo então os seus territórios entre parentes e ministros, após o que, na versão hindu da lenda, que deve ser 
a original, se teria retirado - como modernamente continuavam a fazer, por exemplo, os reis de Cochim - para fazer vida ascética num turucol ou pagode, segundo algumas tradições o templo de Tiruvañjikkuḷam, junto a Cranganor, onde é venerada a sua estátua. Noutras versões da lenda ter-se-ia convertido ao budismo e feito monge, ao passo que na versão cristã se teria convertido ao cristianismo e partido em peregrinação para o túmulo de S. Tomé em Meliapor, na costa do Choramândel. Na versão muçulmana, a mais difundida, que Camões põe em verso n'Os Lusíadas, ${ }^{55}$ teria, ao invés, aderido ao islão e partido para Meca. Seja como for, a era de Coulão continua a ser utilizada no Malabar, contando-se os anos, sempre solares, pelo ano corrente (vartamâna), no norte do Quêrala em estilo kanyâdi (com o ano a começar no signo da Virgem), no sul em estilo simhâdi (a começar no Leão).

Uma era curiosa, embora muito pouco usada, é a era Veppu ou Puduveppu, isto é, "de Vaipim" ou "da nova Vaipim", que se inicia em 1341, quando uma cheia excepcional do rio Periyâr, que até aí apenas tinha saída para o mar em Cranganor, rasgou a barra de Cochim, transformando assim em ilha a península de Vaipim. É usada sobretudo pelos cristãos da ilha.

Uma outra era, curiosa mas de uso efémero, é a "era divina" (ta'rîkh-i Ilahî) estabelecida pelo grão-mogol Akbar (r. 1556-1605), aquando da sua tentativa de unir os seus súbditos em torno de uma religião universal, a "religião de Deus" (dîn-i Ilahî), máximo divisor comum entre o islão, o hinduismo e o cristianismo que lhe inculcavam os jesuítas portugueses estabelecidos na sua corte. Data da sua subida ao trono (14 de Fevereio de 1556), mas foi abolida por seu neto Shâh Jahân (r. 1627-1658). Baseava-se no calendário persa, que é solar, com o início do ano no nou rûz (lit. "novo dia", a festa do ano novo) que coincide com o equinócio da primavera, embora compute os anos pela Hégira (622 A. D.). Assim, conquanto contados a partir da mesma data, os anos persas não têm a mesma numeração que os anos árabes, porque estes são de 354 ou 355 dias e aqueles de 365 ou 366. Os muçulmanos da Índia usam normalmente o calendário árabe, puramente lunar, cujo desfasamento do ano solar aumenta cada ano de 11 dias, de modo que 32 anos civis persas, hindus ou cristãos correspondem a 33 anos muçulmanos. A conversão de uma era à outra apenas com tabelas se pode fazer comodamente. ${ }^{56}$

Quanto aos cristãos da Índia, usaram até à chegada dos portugueses a era dos Selêucidas, dita "dos gregos infiéis", que começa com a subida ao trono de Seleuco Nicátor, um dos diádocos de Alexandre Magno, em 312 A. C. Às vezes designada impropriamente por "era de Alexandre" (que na realidade falecera em Babilónia em Junho de 323), é a era normalmente usada pelos cristãos siríacos, tanto jacobitas como nestorianos. Por influência portuguesa os cristãos do Malabar começaram a datar os anos do Nascimento de Cristo: assim sucede já no Cod. Syr. Vat. III, copiado em 1558 em Angamale e no Cod. Syr. Vat. LXXXV, de 1562. No Cod. Syr. Vat. II, de 1558 aparecem lado a lado a era cristã, a dos Selêucidas e a de Coulão.

61 Um curioso uso que se encontra tanto na Índia como nos países indianizados do Sueste Asiático, nomeadamente em Java, é o uso da datação por cronogramas. Trata-se geralmente de frases simbólicas ou pequenos poemas, em que atribuindo às letras o seu valor numérico, se consegue ler uma data, assim indicada de forma críptica. 0 uso sobreviveu entre os muçulmanos da Índia e ocorre muitas vezes nas crónicas indo-persas. Sirva de exemplo um cronograma relacionado com a história portuguesa: o que dá a data da fortificação da vila de Surate por Khodâvand Khân, capitão local ao serviço do sultão do Guzerate, em 947 A. H. (1540 A. D.), através de um verso persa atribuído a Maulâ 
Mohammad Astrâbâdî: Sadd bawad bar sinâ ô jân-e farangi in banầ e!, "que seja um obstáculo ao ímpeto e à exaltação dos frangues esta construção!".

\section{NOTAS}

1. Na transliteração das palavras sânscritas usámos o sistema adoptado há já mais de um século pela Convenção dos Orientalistas, substituindo contudo, por razões práticas, o makron (-), que indica as vogais longas, pelo acento circunflexo; há apenas a notar que as letras ponteadas por baixo notam consoantes retroflexas (pronunciadas com a língua a tocar o céu da boca e não os dentes), que o $c$ nota uma africada palatal surda idêntica ao ch transmontano ou castelhano (tx), e o ç (usado facultativamente em vez de s com acento agudo que evitámos por razões técnicas) uma chiante palatal surda idêntica ao nosso $x$ em enxame. Mantivemos, contudo, a forma tradicional portuguesa dos topónimos que a têm. Na interpretação dos termos sanscríticos de que se dá o significado servimo-nos essencialmente de Sir Monier Monier-Williams , A Sanskrit-English Dictionary, etymologically and philologically arranged with special referentes to cognate Indo-European Languages, Clarendon Press, Oxford, 1899 [reimp. 1979], e de Otto Böhtlingk \& Rudolph Roth, Sanskrit-Wörterbuch, herausgegeben von der Kaiserlichen Akademie der Wissenschafte, bearbeitet von..., 7 vols., S. Petersburgo, 1855-75 [reimp. Motilal Banarsidas, Delhi, 2000]. As raras palavras chinesas que ocorrem vão transcritas pelo sistema de Wade, e as árabes por um sistema quase idêntico ao adoptado na Encylopédie de l'Islam, com apenas pequenas diferenças que se reconhecem imedatamente e por isso não requerem explicação.

2. Cf. J. Duncan M. Derrett, Religion, Law and the State in India, Faber and Faber, Londres, 1968.

3. Vide Joseph Needham, Science and Techology in China, vol. 3, Cambridge University Press, 1959, pp. 186 \& ss.

4. Shu Ching, I, i, 3: vide Séraphin Couvreur, Chou King - Les Annales de la Chine, Cathasia, Paris (1950), p. 3.

5. Sobre este personagem, de que voltaremos a falar, veja-se D. J. Boilot, art' "al-Bîrûnî (Bêrûnî) Abû-l Rayhân Muhammad b. Ahmad" in Encyclopédie de l'Islam, nouvelle édition, vol. I, E. J. Brill \& G.-P. Maisonneuve, Leida \& Paris, 1960, s. v.

6. Dr. Edward Sachau, Alberuni's India - An account of the religion, philosophy, literature, geography, chronology, astronomy, customs, laws and astrology of India about 1030, edited with notes and indices by..., 2 vols, Londres, 1888 [reimp. Atlantic Publishers \& Distributors, Nova Delhi, 1989], cap. XIV, pp. 152-153.

7. Sobre este sistema - um dos seis darçanas ou sistemas clássicos de filosofia reputados ortodoxos pelos hindus - pode ver-se S. Radhakrishnan, Indian Philosophy, George Allen \& Unwin, Londres, 1923 [reimp. 1948], Vol. II, pp. 374-429; ou, mais sucintamente, Jean Filliozat, Les philosophies de l'Inde, Que sais-je?, P.U.F., Paris, 1970, pp. 53-55.

8. Baseámo-nos essencialmente sobre o capítulo de J. Filliozat acerca da astronomia indiana in Louis Renou \& Jean Filliozat, L'Inde Classique - Manuel des Études Indiennes, vol. II, École Française d'Extrême-Orient, Paris, 1953 [reimp. 1985], pp. 177-194; servimo-nos igualmente de S. N. Sen "Astronomy" in D. M. Bose, S. N. Sen \& B. V. Subbarayappa (ed.), A concise History of Science in India , Indian National Science Academy, Nova Delhi, 1971 [reimp. 1989], pp. 58-135. Por môr de brevidade citaremos em princípio apenas uma vez as obras sobre que fundamentalmente nos baseámos, conquanto as tenhamos utilizado recorrentemente. 
9. Sobre as escolas vêdicas vide Renou \& Filliozat, L'Inde Classique, vol. I, §§ 614-616, pp. 310-313. 10. Designa-se por ano trópico o período de tempo que medeia entre dois equinócios da primavera no hemisfério norte, ou, em outros termos, duas passagens do Sol verdadeiro pelo ponto vernal (o ponto onde a eclíptica intercepta o equador celeste, que no seu movimento aparente o Sol atravessa de sul para norte, o que marca o equinócio da primavera). Como veremos, a duração do ano trópico - que é o que dita a rotação das estações e é por isso o único utilizado para fins práticos - não é exactamente igual à do ano sideral nem à do ano anomalístico, que a seu tempo definiremos. Continuaremos a dar em nota a explicação sumária dos termos técnicos que nos forem aparecendo, embora o leitor menos familiarizado com a terminologia astronómica possa refrescar facilmente a memória consultando uma enciclopédia ou um bom dicionário. Além disso servimo-nos das seguintes obras: F. Tisserand \& H. Andoyer, Leçons de Cosmographie, $4^{\mathrm{a}}$ ed., Paris, 1907; e Pavel Bakulin, Eduard Kononovitch \& Vassili Moroz, Curso de Astronomia, Editora Mir, Moscovo, (1988).

11. Rgveda, maṇdala [livro] I, sûkta [hino] 164, verso 48; utilizámos a edição de Ravi Prakash Arya (Rgveda Saṃhitâ, Sanskrit text, English translation and notes, according to the translation of H. H. Wilson and Bhâsya of Sâyanââarya, edited \& revised with an exhaustive introduction and notes by 5 vols., Parimal Publications, Delhi, $2^{\mathrm{a}}$ ed., 2001, vol. I, pp. 434-435; pode comparar-se a tradução francesa de A. Langlois (Rig-Véda ou Livre des Hymnes, traduit du sanskrit par..., 2e éd., revue, corrigée et augmentée d'un índex analytique par Ph.- Ed. Foucaux, Jean Maisonneuve Éd., Paris, 1984), pp. 150 [note-se que esta edição segue a divisão do Rgveda em oito aștakas, subdivididos cada um em oito adhyâyas ou "leituras", formadas cada uma de uma trintena de vargas, por seu turno reunião de 3 a 8 rg (versos ou dísticos) cada um, divisão que coexiste com uma outra, também tradicional e mais prática, em dez livros ou mandalas, formados de um número variável de hinos].

12. Rgveda, mandala I, sûkta 25, verso 8; tradução francesa de A. Langlois, p. 55.

13. Atharvaveda, kânda [livro] XIII, anuvâka [capítulo ou hino] iii, verso 8. Sevimo-nos da edição de Devi Chand (1880-1965) (The Atharvaveda, Sanskrit text with English translation by..., Munshiram Manoharlal Pub., Nova Delhi, 1995, p. 594) mas apartámo-nos da sua tradução, que nos parece demasiado livre, vertendo mâsam, lit. "mês" por object.

14. Subhash Kak, "Astronomy and its Role in Vedic Culture" in D. P. Chattopadhyaya (ed.), History of Science, Philosophy and Culture in Indian Civilization, vol. I, p. I, The Dawn of Indian Civilization (up to c. 600 BC), edited by G. C. Pande, PHISC, Centre for Studies in Civilization, Nova Delhi, 1999, pp. 615-634.

15. Revolução sideral é o tempo que a Lua demora a dar a volta ao zodíaco e projectar-se de novo sobre a mesma constelação, ou, em outros termos, a aumentar de $360^{\circ}$ a sua longitude celeste. É mais curta que a revolução sinódica ou lunação (o tempo que decorre entre duas luas-novas, ou, em outros termos, o tempo necessário para que a diferença entre as longitudes do Sol e da Lua aumente de $360^{\circ}$ ), visto a Terra mover-se e a Lua ter de acompanhar o seu movimento até ocupar a mesma posição em relação ao Sol; a revolução sinódica, que dita as fases da Lua e está por isso na origem quer da semana quer do mês lunar, dura na realidade 29 dias, 12 horas, 44 minutos e 2,9 segundos.

16. Needham, op. cit., pp. 229 \& ss. Pelo menos noutros aspectos a influência da astronomia indiana na China está historicamente comprovada: sob a dinastia Sui, em 610 A. D., mencionamse na China as versões de 4 tratados astronómicos ditos "dos brâmanes" (po-lo-men); sob os T'ang (618-907) sabe-se de um certo Ch'u-t'an Hsi-ta (provavelmente transcrição de Gautama Siddha ou Siddhârta), que traduziu para chinês, sob o título de Chiu-chi-li um calendário indiano; etc. - vide S. N. Sen, op. cit., p. 133.

17. Tanto a longitude celeste como a ascensão recta de um astro ou de um lugar do firmamento se medem a partir do ponto vernal, que já definimos acima, aquela sobre a eclíptica esta sobre o equador celeste; as coordenadas correlativas são no primeiro caso a latitude celeste no segundo a 
declinação. Assim a coordenada celeste que corresponde à latitude terrestre (distância angular do ponto dado ao equador) não é a latitude celeste mas a declinação, tal como a outra coordenada não é nesse caso a longitude celeste mas a ascensão recta. Ao contrário da chinesa, a astronomia indiana tradicional usa em geral como coordenada a longitude celeste, mas abstraindo da precessão dos equinócios, fenómeno que explicaremos mais abaixo (nota 38); isto é, mede-a a partir da posição que o ponto vernal ocupava no ano 3600 do kaliyuga (conceito que explicaremos mais abaixo), correspondente a 499 A. D., de modo que para obter a posição real de um astro em dado momento é necessário introduzir-lhe uma correcção (vide infra nota 39). Diz-se, por isso, que a astronomia indiana utiliza longitudes siderais ao passo que a nossa utiliza longitudes trópicas.

18. Cf. P. Kunitzsch, art " "al-Manâzil" in Encyclopédie de l'Islam, vol. VI, s. v.

19. Vide o apêndice 3, "Notions de chronologie", ao vol. II de L'Inde Classique, cit. supra; a tabela geral dos nakșatras encontra-se a pp. 729-730.

20. Vide S. B. Dikshit [\& R. Sewell], The Indian Calendar with Tables for the Conversion of Hindu and Muhammadan into A. D. Dates, and vice-versa, Londres, 1896; reedição abreviada, de que nos servimos: "Indian Calendar: The Pañcânga", in Studies in the History of Science in India, edited by Debiprasad Chattopadhyaya, vol. II, Asha Jyoti, Nova Delhi, 1992, pp. 751-763.

21. Há que notar que a Lua apenas aproximadamente se move sobre o zodíaco (zona da esfera celeste envolvendo a eclíptica que, no seu movimento aparente, o Sol percorre durante um ano) já que o plano da sua translação faz com a eclíptica um ângulo médio de 5o 8' 48" (oscilando, ao longo de um ciclo de 18 anos e 2/3, entre 5o 0' 1" e 5o 17' 35"). Conforme a inclinação da órbita lunar sobre a eclíptica, que varia constantemente, se adicione a esta ou se lhe diminua, o seu ângulo com o equador varia entre $18^{\circ} 10^{\prime}$ e $28^{\circ} 45^{\prime}$; consequentemente a declinação da Lua pode assumir qualquer valor entre $28^{\circ} 45^{\prime} \mathrm{N}$ e $28^{\circ} 45^{\prime} \mathrm{S}$.

22. Vide G. Thibaut "Contributions to the explanation of the Jyotisa-vedânga" in Journal of the Asiatic Society of Bengal, 1877, pp. 411-437, reproduzido in Studies in the History of Science in India, cit. supra, pp. 479-502; cf. L'Inde Classique, vol. I, § 612.

23. Cf. S. N. Jha, "Vedânga Astronomy" in Chattopadhyaya / Pande (ed.), op. cit., pp. 699-717.

24. Vide Hermann Jacobi, "The Computation of Hindu Dates in Inscriptions, \&c." in Epigraphia Indica, vol. 1 (Calcuttá, 1882) [reimp. Archeological Survey of India, Nova Delhi, 1983], pp. 403-460, com numerosas tabelas astronómicas que permitem fazer a conversão das datas.

25. Recordem-se as duas primeiras leis de Kepler. $1^{\mathrm{a}}$ os planetas descrevem em torno do Sol [e a Lua em torno da Terra] elipses, de que o Sol ocupa um dos focos; $2^{\mathrm{a}}$ o raio vector dirigido do Sol ao planeta [e semelhantemente da Terra à Lua] varre áreas iguais em tempos iguais. As órbitas não são por conseguinte circulares, com o astro principal a ocupar o centro, mas elípticas, com o astro principal num dos focos; e como o que se mantém constante é a área varrida pelo raio vector dirigido da Terra à Lua (e semelhantemente do Sol à Terra) e não o caminho percorrido pela Lua (ou pela Terra, no seu movimento em torno do Sol), a velocidade desta cresce desde o momento do seu apogeu (local da trajectória em que se encontra mais afastada da Terra) até o do seu perigeu (local da trajectória em que se encontra mais próxima da Terra). No caso dos planetas trata-se de afélio e periélio em vez de apogeu e perigeu; no do Sol, uma vez que sabemos hoje que na realidade é a Terra que se move em seu torno e não ele em torno da Terra, é teoricamente mais correcto empregar os termos afélio e periélio; na prática é indiferente, visto ser o mesmo dizer que a Terra está no ponto mais próximo do Sol ou que o Sol está no ponto mais próximo da Terra. Como a antiga astronomia, ocidental ou indiana, lida com movimentos aparentes dos astros e não com movimentos reais continuaremos, mesmo no caso do Sol, a usar os termos apogeu e perigeu em vez de afélio e periélio.

26. Dia sideral é o intervalo entre duas passagens do ponto vernal pelo meridiano do lugar; devido ao movimento de translação da Terra em torno do Sol o dia sideral é menor que o dia solar, pois no decurso de um ano o Sol passa 365 vezes pelo meridiano de qualquer lugar, ao passo que o ponto vernal (ou uma estrela fixa) passa 366. Em rigor, devido à precessão dos equinócios 
de que voltaremos a falar (nota 38), há contudo uma diferença de 1/120 de segundo (o que perfaz um dia em 26.000 anos) entre duas passagens de uma estrela fixa e duas passagens do ponto vernal por um dado meridiano, diferença tão pequena que na prática se pode desprezar. 0 dia sideral medido por duas passagens de uma estrela fixa pelo meridiano é a verdadeira medida da rotação da Terra; o dia solar é mais longo $1 / 366$, correspondendo a diferença à deslocação da Terra sobre a eclíptica no mesmo período.

27. Reproduzimos os números dados por Thibault, op. cit. supra, que aliás coincidem com os apresentados por S. Kak, op. cit. supra.

28. Trata-se, com efeito, apenas de um valor médio, já que, em virtude da $2^{\mathrm{a}}$ lei de Kepler, a deslocação do Sol sobre a eclíptica não é uniforme; o tempo real gasto pelo Sol para percorrer um grau da eclíptica tem um mínimo no perigeu, um máximo no apogeu e valores medianos nos períodos intermédios.

29. Com efeito a relação entre a duração do dia solar (d), medida em horas, a latitude do lugar $(\varphi)$ e a declinação do Sol $(\delta)$ nesse dia, estas medidas em graus, é dada pela fórmula:

$\mathrm{d}=\underline{2 \operatorname{arc} \cos (\operatorname{tg} \varphi \operatorname{tg} \delta)}$

15.

30. Vide Sarva Narayan Jha "Astronomical and Astrological Ideas between the Vedânga-Jyotișa and Âryabațța" in D. P. Chattopadhyaya (ed.), History of Science, Philosophy..., vol. 1, p. 2, Life, Thought and Culture in India (from c. 600 B. C. to c. AD 300), Nova Delhi, 2001, pp. 842-865; Subhash Kak, "Development of Astronomy between the Vedânga-Jyotiṣa and Âryabatța ", ibidem, pp. 866-885; E. Burgess "The Astronomical Siddhânta-s" in Journal of the American Oriental Society, VI (1859-60), pp. 141-500; republicado em livro com o título Translation of Sûrya-siddhânta: a Text-book of Hindu astronomy with Notes and an Appendix, edited by Phanindranath Gangooly with an Introduction by P. C. Sengupta, University of Calcutta, 1935; parcialmente reproduzido in D. Chattopadhyaya, Studies in the History of Science in India, vol. II, pp. 503-509, de que nos servimos.

31. Prescindindo de detalhes matemáticos, a anomalia é, em breves palavras, a diferença entre a posição ocupada por um astro, que descreve uma órbita elíptica, e a posição que ocuparia no mesmo momento se a sua órbita fosse circular. A antiga astronomia indiana, como a astronomia ocidental antes de Kepler (1571-1630), conhecia a existência da anomalia, conseguia medi-la, mas não a interpretava correctamente imaginando que os astros descreviam epiciclos, i. e., pequenos círculos imaginários em torno de sucessivos pontos do círculo que se supunha constituir a sua órbita teórica. Essas perturbações eram atribuídas à acção de uma das sete espécies de vento cósmico, considerado o motor universal, designado por pravaha ("vector, promotor").

32. A equação do centro é a diferença angular entre a posição ocupada pela Lua (ou pelo Sol ou por qualquer planeta) num dado momento e a posição que ocuparia se a sua velocidade de translação, em vez de obedecer à segunda lei de Kepler, fosse uniforme; é nula no apogeu e no perigeu atingindo de permeio valores que no caso do Sol variam entre - $1^{\circ} 55^{\prime} 33^{\prime \prime}$ e $1^{\circ} 55^{\prime}$ 33"; no caso da Lua entre -6을 $20^{\prime}$ e $6^{\circ} 20^{\prime}$.

33. Paralaxe é a diferença entre a direcção em que num dado momento um astro é observado de um dado lugar e a direcção em que seria observado do centro da Terra; na prática usa-se sobretudo a paralaxe horizontal (i. e., medida no momento em que o astro rasa o horizonte do lugar) que permite medir comodamente a distância absoluta do astro à Terra pela simples resolução trigonométrica de um triângulo.

34. Na realidade os eclipses podem ser facilmente preditos por um processo semi-empírico, se se tiver em conta que o saros (período ao longo do qual os eclipses do Sol e da Lua se repetem pela mesma ordem aos mesmos intervalos), descoberto, ao que parece pelos caldeus, é de 223 lunações ou 18 anos e 11,3 dias, produzindo-se ao longo dele 75 eclipses.

35. Revolução anomalística é o intervalo de tempo que medeia entre duas passagens da Lua ou do Sol pelo perigeu, que definem num caso o mês anomalístico no outro o ano anomalístico. A linha das ápsides (a linha que une o perigeu ao apogeu, coincidente com o eixo maior da elipse que 
constitui a órbita do astro) move-se, no caso do Sol, no sentido directo, crescendo a sua longitude à razão de $11^{\prime}, 7$ por ano. 0 ano anomalístico é assim ligeiramente mais longo que o ano trópico, correspondendo a 365 dias, 8 horas, 13 minutos e 48,61 segundos; por isso o afélio, que hoje tem lugar a 1 de Julho (tal como o periélio, que hoje tem lugar a 1 de Janeiro) tinha há $c .2000$ anos lugar c. 6,5 dias mais cedo. No caso da Lua, o mês anomalístico tem a duração de 27,55 dias solares médios, mais longo também que a revolução sideral da Lua que dura 27,32 dias. A determinação do apogeu e do perigeu faz-se com base na observação do diâmetro aparente do Sol (ou da Lua), já que a distância relativa da Terra a um astro varia na razão inversa do seno do semi-diâmetro aparente deste.

36. Não confundir Budha - o deus tutelar do planeta Mercúrio, filho espúrio de Târâ, esposa de Bri haspati (Júpiter) e de Soma (divindade masculina da Lua) - com Buddha, epíteto de Siddhârta Gautama, o fundador do budismo, que é uma personagem histórica.

37. Nascimento helíaco de um astro é o momento em que este, após uma conjunção com o Sol que o torna invisível, aparece pela primeira vez ao crepúsculo do amanhecer; ocaso helíaco é o momento da sua derradeira aparição ao crepúsculo do entardecer, antes de uma conjunção com o Sol que o faz desaparecer. Em astrologia os nascimentos e ocasos helíacos tinham uma grande importância; os caldeus utilizavam-nos para determinar o início dos meses solares, e os egípcios, cujo calendário não conhecia ainda os anos bissextos, denominavam de período sotíaco o lapso de 1600 anos que medeia entre dois nascimentos helíacos de Sothis (ou seja, da estrela Sirius, $\alpha$ do Cão Maior), que vinha restabelecer, embora por quatro anos apenas, a correspondência entre o calendário civil e o ano astronómico.

38. A precessão dos equinócios resulta de um movimento do eixo da Terra que, conservando a mesma inclinação sobre a eclíptica $\left(90^{\circ}-\right.$ c. $\left.23^{\circ} 30^{\prime}=c .66^{\circ} 30^{\prime}\right)$, descreve no sentido retrógrado, no espaço de 26.000 anos, um movimento circular em torno de si mesmo, desenhando no espaço dois cones simétricos unidos pelo vértice. 0 polo norte, que hoje aponta aproximadamente para a Estrela Polar, desenha assim na abóbada celeste, em torno do polo da eclíptica, um círculo de $c$. $23^{\circ}$ 30' de raio; é por isso que há 4.000 anos a estrela do norte não era a Polar mas a $\alpha$ do Dragão, e que daqui a 12.000 anos será a Vega, $\alpha$ da Lira. Em consequência desse movimento, a intecepção do equador celeste com a eclíptica move-se no sentido retrógrado, de modo que os lugares dos equinócios (pontos em que a eclíptica intercepta o equador celeste) se deslocam à razão de 50",26 por ano, o que por seu turno traz como consequência que os equinócios tenham lugar cada ano 20 minutos mais cedo que no ano anterior, de onde o nome do movimento. $\mathrm{O}$ ano trópico tem por isso menos 20 minutos que o ano sideral, de que já falámos. Hoje sabe-se que a inclinação da eclíptica, que orça os 23ํ 30', oscila periodicamente ao longo de um período de 18 2/3 anos, acompanhando o movimento de rotação dos nodos da Lua (pontos em que a órbita lunar intercepta o equador e onde, por consequência, podem ter lugar os eclipses), à razão de 0",48 ao ano; mas esta pequena oscilação, chamada nutação, que não perfaz senão 18 " entre os seus valores extremos ao longo do ciclo de 18 anos e 2/3, apenas em 1736 foi descoberta pelo astrónomo inglês Bradley, pelo que não temos de nos ocupar dela ao lidar com os antigos tratados de astronomia que a não levam em conta.

39. Uma vez que, como adiantámos já, os astrónomos hindus medem as longitudes celestes não do ponto vernal actual, mas da posição que ocupava na esfera celeste no ano 3600 do kaliyuga (499 A. D.), há que levar em conta este valor para determinar a posição de um astro em dado momento; a correcção a introduzir pode calcular-se pela seguinte regra prática: é, em graus de arco, igual à diferença, em anos, entre o momento em causa e o ano inicial do kaliyuga, multiplicada por $3 / 200$. Esse valor tem de ser igualmente levado em conta quando se trata de determinar a hora solar média de um dado lugar, que depende da sua longitude terrestre, medida em relação a Lańka, e da longitude tropical do sol médio, que é idêntica à longitude sideral mais a correcção assim calculada. 
40. Vide H. H. Wilson, The Vishṇu Purâna, a System of Hindu Mithology and Tradition, translated from the Sanskrit and illustrated by notes derived from other Purânas by..., Punthi Pustak, Calcutta, 1972.

41. I, iii; ed. cit. p. 21.

42. Cf. Rajesh Kochhar, "Pre-telescopic Astronomy in India" in D. P. Chattopadhyaya (ed.), History of Science..., vol. III, p. 1, History of Indian Science, technology and Culture, AD 1000-1800, edited by A. Rahman, pp. 171-197; S. A. H. Rizvi, "Glimpses of Astronomy in Medieval India", ibidem, pp. 198-220.

43. Para mais pormenores, vide Bhau Daji, "Brief Notes on the Age and Authenticity of the Works of Âryabața, Varâhamihira, Brahmagupta, Bhațtotpala and Bhâskarâcârya" in Journal of the Royal Asiatic Society of Great Britain \& Ireland, 1865, pp. 392-418: versão abreviada, de que nos servimos, in D. Chattopadhyaya, Studies in the History of Science..., pp. 518-536; P. C. Sengupta, "Âryabața, the Father of Indian Epyciclic Astronomy", ibidem, pp. 602-618 (reproduzido de Journal of the Department of Letters, University of Calcutta, 1929, pp. 1-56).

44. H. Kern, The Bṛhatsaṃhitâ: a Treatise on Astrology, Bibliotheca Indica, 48, Asiatic Society, Calcutta, 1865 (versão abreviada, de que nos servimos: "The Bṛhatsaṃhitâ of Varâhamihira" in D. Chattopadhyaya, Studies in the History of Science..., pp. 591-601).

45. Cf. P. C. Sengupta, "Brahmagupta's Khaṇdakhâdyaka" (reprodução da introdução à tradução inglesa desse tratado, Universidade de Calcutá, 1934), in D. Chattopadhyaya, Studies in the History of Science..., pp. 602-618.

46. Yoga (da $\sqrt{ }$ yuj- , "unir"), significa também em astronomia "conjunção de astros", acepção a não confundir com esta acepção técnica; os significados "união da alma com Deus", "união das faculdades do homem", "nome de uma disciplina psico-somática antiquíssima na Índia" e "nome de um dos seis darçanas ou sistemas de filosofia hindu reputados ortodoxos" não se prestam, neste caso, a confusão.

47. Dikshit \& Sewell (op. cit., pp. 760-761) informam-nos de que o Sûryasiddhânta atribui ao çodhya - que os autores consideram equivalente à nossa equação do tempo - da meșasamikrânti o valor de 2 dias, 10 ghațikâs, 14 palas e 30 vipalas, ao passo que Âryabata o computa em 2 dias, 8 ghațikâs, 51 palas e 15 vipalas. Trata-se, necessariamente, de valores acumulados, devido à recessão secular do periélio terrestre, mas os autores não indicam desde quando. Com efeito, a equação do tempo (a diferença entre o tempo solar médio, que medem os nossos relógios, e o tempo solar verdadeiro, medido entre duas passagens do Sol verdadeiro pelo meridiano), que hoje é nula a 15 de Abril, 14 de Junho, 1 de Setembro e 24 de Dezembro, não ultrapassa os +14 minutos (actualmente a 11 de Fevereiro) nem os -16 minutos (a 2 de Novembro), o que fica muito distante dos 2 dias e tal dados por aqueles tratados astronómicos indianos. Recorde-se que a equação do tempo representa a combinação de duas funções sinusoidais: uma sinusóide representando a equação do centro do Sol (já definida acima, que resulta da $2^{\mathrm{a}}$ lei de Kepler) e outra representando a equação da inclinação da eclíptica, ou seja variação da projecção da eclíptica, por onde se move o Sol, sobre o equador celeste, a que são perpendiculares os meridianos que definem o meio-dia solar; por outras palavras, esta equação dá-nos a relação entre a longitude do sol médio - um sol fictício de movimento uniforme, abstraindo, portanto, da $2^{a}$ lei de Kepler - e a sua ascensão recta. Para a mesma diferença de longitudes celestes a diferença de ascensão recta é menor nos equinócios, onde a eclíptica intercepta os meridianos com um ângulo de $\pm 66^{\circ} 30^{\prime}$ (ângulo cujo seno é 0,91706 ) que nos solstícios, onde é perpendicular aos meridianos (interceptando-os, portanto a $90^{\circ}$, ângulo cujo seno é igual à unidade), já que num triângulo esférico os senos dos lados são directamente proporcionais aos senos dos ângulos opostos. Presumimos que o valor acumulado se conte desde o início do kaliyuga. o primitivo Âryasiddhânta ainda imaginava que o apogeu do Sol era fixo, sito a uma longitude de 78ㅜㅇㅢ os outros siddhântas consideram já que se desloca, calculando que o seu movimento tenha uma periodicidade que o Sûryasiddhânta computa em 387 revoluções por kalpa (o que equivale a uma revolução em 11.162.790 anos, período muito superior ao real, que é de $c$. 
59.000 anos); a versão corrigida do Âryasiddhânta computa-a em 461 por kalpa e o Brahmasiddhânta em 480. O Sûryasiddhânta calcula a longitude do apogeu solar no início do kaliyuga em 77ํ7' 48” e a da anomalia média do Sol em 282 $52^{\prime} 12^{\prime \prime}$; os outros dois tratados computam-nas ambos em $77^{\circ}$ $45^{\prime} 36^{\prime \prime}$ e $282^{\circ} 14^{\prime} 24^{\prime \prime}$, respectivamente.

48. Desprezando o $20^{\circ}$ nakșatra, de dimensões mais reduzidas, a extensão média de cada nakșatra é de $13^{\circ} 20^{\prime}$, ao passo que a de cada signo é de $30^{\circ}$; cabem portanto em média c. $21 / 4$ nakșatras em cada signo, pelo que o plenilúnio, que pode ter lugar a qualquer hora do dia e em qualquer dia do mês (ou, noutros termos, a qualquer longitude da Lua), pode cair dentro de qualquer dos dois nakșatras ou no quarto de nakșatra remanescente. Essa possibilidade existe a fortiori se se contarem 28 nakșatras (o que dá uma extensão média de $12^{\circ}$ 51' para cada um, exactamente $21 / 3$ por signo).

49. Angelus Francis Xavier Maffei, Konkani - English Dictionary, Cananor, 1883 [reimp. Asian Educational Services, Nova Delhi \& Madrasta, 1990], pp. 147-148.

50. Basta que o apogeu da Lua coincida com o perigeu do Sol.

51. Terminados em i longo, estes nomes são femininos; não concordam portanto com tithi, que é masculino, mas com a variante tithî, que é feminina.

52. Podem ver-se in H. Jacobi "The Computation..." (Epigraphia Indica, vol. I, pp. 407-460).

53. Achar-se-á uma lista assaz completa in L'Inde Classique, II, pp. 736-738.

54. Podem ver-se in D. G. Stibbe \& C. Spat, Encyclopaedie van Nederlansch-Indië, $2^{a}$ ed., vol. V (suplemento), Haia \& Leida, 1927, s. v. "Tijdrekening" (pp. 65-79).

55. VII, 32-37.

56. Pode ver-se uma tabela de correspondências dos anos da Hégira aos anos julianos (depois de 1582 , gregorianos) até 2000, com a data do ano-novo em cada ano do calendário maometano in $\mathrm{A}$. Cappelli, Cronologia, Cronografia e Calendario Perpetuo, dal principio dell'èra cristiana ai nostri giorni, Ed-Ulrico Heopli,6a ed., 1988, pp. 169-176.

\section{RESUMOS}

Os sistemas de cômputo do tempo na Índia são extremamente complexos, devido a dois factores: em primeiro lugar a coexistência não só de diversas teorias e tabelas astronómicas mas também de diferentes calendários, que em parte resulta de a Índia raramente ao longo da sua história ter constituído uma unidade política; em segundo lugar uma grande preocupação, quiçá de origem mágica, com a objectividade astronómica dos dados utilizados no cômputo do tempo. Do primeiro factor indicado resultam, por exemplo, a coexistência de calendários solares, predominantes em certas regiões, com calendários luni-solares nas restantes, a contagem dos meses a partir da luanova ou da lua-cheia, consoante as zonas, etc. Do segundo resultam por exemplo: a adopção de estranhas unidades de tempo, como o tithi (que se pode definir como a trigésima parte de uma lunação, ou, em outros termos, o tempo que, após uma conjunção com o Sol ou seja uma luanova, a Lua demora a afastar-se deste $12^{\circ}$ sobre o zodíaco); a entrada em conta da precessão dos equinócios para efeitos de determinação do início dos signos do zodíaco; etc. o presente artigo procura resumir e explicar essa diversidade de uma perspectiva histórica, pondo-a em relação com a evolução da astronomia indiana.

The systems of time reckoning in India are extremely complex, owing mainly to two factors. On the one hand, we have the lack of political unity of India during most periods of her history, 
which allowed the coexistente not only of different astronomic theories and tables but also of different civil calendars. On the other hand we have a strong desire of astronomic objectivity of all measurements used for time reckoning, which is perhaps of magic origin. This led to the adoption of strange unities of time, such as the tithi (which can be defined as the thirtieth part of a lunation, or, in other terms, the time the Moon takes, after a conjunction with the Sun, to get $12^{\circ}$ far from it); and also to the introduction of the precession of the equinoxes into the determination of the signs of Zodiac. The present article tries to explain such features from a historical point of view, linking them to the evolution of Indian astronomic Science.

\section{ÍNDICE}

Keywords: time, calendars, luni-solar, astronomy, zodiac

Palavras-chave: tempo, calendários, luni-solar, astronomia, zodíaco

\section{AUTOR}

\section{LUÍS FILIPE F. R. THOMAZ}

Instituto de Estudos Orientais Universidade Católica Portuguesa

Licenciado em História na Faculdade de Letras da Universidade de Lisboa; licenciado em Estudos Indianos Clássicos em Paris III; foi professor de Sânscrito na FCSH, FLUL e na UCP; doutoramento Honoris Causa pela Universidade Nova de Lisboa, 2002; director do Instituto de Estudos Orientais da UCP onde também é responsável pela cadeira de História Cultural e Civilização da Índia; pertence a diversas sociedades científicas, entre as quais destacamos: Société Asiatique, Paris; Société Française d'Histoire d'Outre-Mer, Paris; Association Française pour les études Indiennes; Centre Nationale de la Recherche Scientifique, Paris (membro associado); European Association for South-East Asian Studies. 